$6{ }^{\mathrm{a}}$ CNRS and University Joseph Fourier, ISTerre/UMR 5275, OSUG/INSU, BP 53, 38041

7 Grenoble Cedex 9, France

$8{ }^{\mathrm{b}}$ CNRS and University Joseph Fourier, IPAG, OSUG/INSU, BP 53, 38041 Grenoble Cedex 9, 9 France

\section{Gas-solid carbonation as a possible source of carbonates in cold planetary environments}

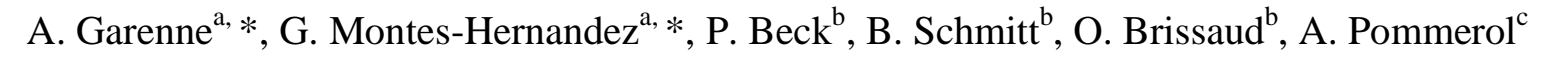

${ }^{c}$ Physikalisches Institut, Universität Bern, Sidlerstrasse 5, CH-3012 Bern, Switzerland

*Corresponding authors: A. Garenne and G. Montes-Hernandez

Tel: Alexandre.Garenne: +33 (0)607912561

German. Montes-Hernandez : +33 (0)683363044

E-mail addresses: alexandre.garenne@obs.ujf-grenoble.fr and german.montes-hernandez@obs.ujfgrenoble.fr

.

.

(

.

.




\section{Abstract}

27 Carbonates are abundant sedimentary minerals at the surface and sub-surface of the Earth and 28 they have been proposed as tracers of liquid water in extraterrestrial environments. Their 29 formation mechanism is since generally associated with aqueous alteration processes. Recently, 30 carbonate minerals have been discovered on Mars' surface by different orbital or rover missions.

31 In particular, the phoenix mission has measured from 1 to $5 \%$ of calcium carbonate (calcite type) 32 within the soil (Smith P.H. et al., 2009). These occurrences have been reported in area were the 33 relative humidity is significantly high (Boynton et al., 2009). The small concentration of 34 carbonates suggests an alternative process on mineral grain surfaces (as suggested by Shaheen et 35 al., 2010) than carbonation in aqueous conditions. Such an observation could rather point toward 36 a possible formation mechanism by dust-gas reaction under current Martian conditions. To 37 understand the mechanism of carbonate formation under conditions relevant to current Martian atmosphere and surface, we designed an experimental setup consisting of an infrared microscope coupled to a cryogenic reaction cell (IR-CryoCell setup). Three different mineral precursors of

40 carbonates ( $\mathrm{Ca}$ and $\mathrm{Mg}$ hydroxides, and a hydrated $\mathrm{Ca}$ silicate formed from $\mathrm{Ca}_{2} \mathrm{SiO}_{4}$ ), low 41 temperature (from -10 to $+30^{\circ} \mathrm{C}$ ), and reduced $\mathrm{CO}_{2}$ pressure (from 100 to 2000 mbar) were 42 utilized to investigate the mechanism of gas-solid carbonation at mineral surfaces. These mineral 43 materials are crucial precursors to form $\mathrm{Ca}$ and $\mathrm{Mg}$ carbonates in humid environments $(0<$ 44 relative humidity $<100 \%$ ) at dust- $\mathrm{CO}_{2}$ or dust-water ice- $\mathrm{CO}_{2}$ interfaces. Our results reveal a 45 significant and fast carbonation process for Ca hydroxide and hydrated Ca silicate. Conversely, 46 only a moderate carbonation is observed for the Mg hydroxide. These results suggest that gas47 solid carbonation process or carbonate formation at the dust-water ice- $\mathrm{CO}_{2}$ interfaces could be a 
48 currently active Mars' surface process. To the best of our knowledge, we report for the first time

49 that calcium carbonate can be formed at a negative temperature $\left(-10^{\circ} \mathrm{C}\right)$ via gas-solid carbonation

50 of Ca hydroxide. We note that the carbonation process at low temperature $\left(<0^{\circ} \mathrm{C}\right)$ described in the

51 present study could also have important implications on the dust-water ice-CO2 interactions in

52 cold terrestrial environments (e.g. Antarctic).

53

54

55

56

57

58

59 Keywords: Carbonates; Gas-solid carbonation; Mars; Low temperature; Infrared Microscopy; Ca

60 and Mg Hydroxides.

61

62

63

64

65 


\section{Introduction}

The biotic and abiotic (i.e. chemical) formation of carbonates plays a crucial role in the global carbon cycle on Earth. In addition, carbonate minerals often sequester various trace elements (actinides and lanthanides), metalloids, and heavy metals, and thus control in part their global cycling (e.g. Paquette and Reeder, 1995; Stumm and Morgan, 1995; Sigg et al., 2000). In

71 general, carbonate minerals can be formed in natural or artificial environments by three different 72 mechanisms (e.g. Montes-Hernandez et al., 2010a): (1) aqueous nucleation-growth in 73 homogeneous or heterogeneous systems (aqueous conditions), for example, the chemical or 74 biogenic formation of carbonates in lakes, oceans, $\mathrm{CO}_{2}$ storage sites, natural caves; (2) gas-solid 75 carbonation of alkaline minerals (fine particles) in the presence of adsorbed water (water 76 humidity conditions, $0<$ water activity $<1$ ), for example carbonate formation in water77 unsaturated soils, in terrestrial or extraterrestrial aerosols (Shaheen et al., 2010). This water has 78 an important role in the surface chemistry of minerals as was shown by Galhotra et al., (2009) 79 and Baltrusaitis and Grassian (2005) with zeolites and iron oxide surfaces; (3) dry gas-solid 80 carbonation of granular/porous materials (dry conditions, water activity $\approx 0$ ), for example, the 81 industrial mineralization, recovery or capture of $\mathrm{CO}_{2}$ at high temperatures in presence of alkaline 82 binary oxides $(\mathrm{CaO}, \mathrm{MgO})$ or metastable, nanoparticle alkaline silicates (Montes-Hernandez et 83 al., 2012).

In the Planetary Sciences context, carbonates are generally considered as indicators of aqueous alteration processes (Bandfield et al., 2003; Milliken and Rivkin, 2009; Boynton et al., 2009; Ehlmann et al., 2008; Michalski and Niles, 2010). In the case of Mars, huge deposits of

87 surface carbonates remained undetected for a long period, and their suspected absence was used 4 
to constrain the chemistry of a putative Martian ocean (Fairén et al., 2004). Evidences are now

89 growing for the presence of carbonates at the surface of the red planet, which include observations of carbonate-rich outcrops (Ehlmann et al., 2008; Michalski and Niles, 2010) as well as carbonates within the Martian dust (Bandfield et al., 2003; Boynton et al., 2009). The aqueous alteration of mafic rocks in the presence of $\mathrm{CO}_{2}$ is certainly an efficient mechanism for carbonate synthesis, an alternative pathway of carbonate synthesis exists, which does not require the presence of liquid water. This pathway involves reaction of a mineral substrate with $\mathrm{CO}_{2}$ in the presence of chemisorbed water (few angstroms to few nm thick layers), and was recently tested and observed for terrestrial aerosols (Shaheen et al., 2010).

Here, we report on an experimental study of the kinetic of carbonation in liquid-water free environment. We designed novel, state of the art experimental setup (IR-CryoCell) to investigate the in-situ gas-solid carbonation (i.e. resolved in time), for temperature and pressure conditions relevant to Mars. We studied carbonate synthesis starting from $\mathrm{Ca}$ and $\mathrm{Mg}$ hydroxides and an amorphous silicate (synthesized from $\mathrm{Ca}_{2} \mathrm{SiO}_{4}$ ), at low temperature (from -10 to $+30^{\circ} \mathrm{C}$ ) and at low $\mathrm{CO}_{2}$ pressure (from 100 to 2000 mbar). These starting materials are known precursors to 103 form respective $\mathrm{Ca}$ and $\mathrm{Mg}$ carbonates in humid environments at dust- $\mathrm{CO}_{2}$ or dust-water ice- $\mathrm{CO}_{2}$ 104 interfaces, at least under «terrestrial » conditions. They also can be expected to occur at the 105 surface of Mars and some asteroids (Mg hydroxide has been described on Ceres). We report here 106 laboratory experiments on gas-solid carbonation process at low temperature $\left(<0^{\circ} \mathrm{C}\right)$, which 107 provides new insights on conditions for carbonate formation. We will show that gas-solid 108 carbonation can occur below the water frost point (at terrestrial atmospheric pressure), with 109 significant implications on the dust/water-ice/ $\mathrm{CO}_{2}$ interactions in cold environments. 


\section{Materials and methods}

111 The experiments were performed using three different materials, $\mathrm{Ca}, \mathrm{Mg}$ hydroxide and a $\mathrm{Ca}$

112 silicate hydrate. $\mathrm{CO}_{2}$ is known to react with surface of $\mathrm{CaO}$ and $\mathrm{MgO}$ by adsorption (Ochs et al., 113 1998a; Ochs et al., 1998b) and produce carbonates as well the importance of OH groups to water 114 adsorption on surfaces (Yamamoto et al., 2008). These substrates were chosen to mimic natural 115 conditions and to catalyze reaction as their surfaces are terminated by $\mathrm{OH}$ groups: i) in order to 116 form $\mathrm{Ca}-\mathrm{Mg}$ carbonate by reaction with $\mathrm{CO}_{2}$, a $\mathrm{Ca}$ and $\mathrm{Mg}$ source is needed; ii) the presence of 117 hydroxyl groups in the starting material was requested to permit auto-catalysis of the reaction 118 (Montes-Hernandez et al., 2010a); iii) the material had to be geologically relevant.

119 Brucite has not been detected on the Martian surface. However, various types of phyllosilicates 120 have been now described over the planet, that are interpreted as aqueous alteration products of 121 mafic rocks (see the recent review by Ehlmann et al., 2011). Such aqueous alteration processes 122 can be accompanied by the production of brucite (Evans, 2008). Identification of brucite by its 123 spectral properties is difficult since no diagnostic band is present in the NIR, with the exception 124 of the 2.7 micrometer feature ubiquitous to almost all $-\mathrm{OH}$ bearing phases. Brucite has been 125 diagnosed on some asteroids from observations in the mid-IR (together with carbonate). It is the case of the largest main-belt object, Ceres. In addition, $\mathrm{MgO}$ has been proposed as a condensation

127 product in some solar nebula models, which should readily transform to brucite in the presence of 128 gaseous water or humidity (Gail and Sedlmayr, 1999).

129 Portlandite has not been reported on Mars either. On Earth, it is almost always found in 130 association with calcium carbonates, and is very difficult to observe due to its high reactivity with $131 \mathrm{CO}_{2}$. We chose to study portlandite because of its high catalytic reactivity which enabled to 6 
132 provide kinetic measurements under some hours. In addition, it is a structural analog to brucite 133 and a number of $\mathrm{X}-(\mathrm{OH})_{2}$ type hydroxide compounds (where $\mathrm{X}=\mathrm{Ni}, \mathrm{Co}, \mathrm{Fe}, \mathrm{Mn}, \mathrm{Cd}$ ). $\mathrm{CaO}$ has 134 also been proposed as an intermediate compound by Shaheen et al. (2010) to explain the 135 formation of calcium carbonate on Mars, which could readily transform to portlandite in the 136 presence of gaseous $\mathrm{H}_{2} \mathrm{O}$ or humidity.

137 Finally, we used an amorphous calcium silicate hydrate synthesized from larnite $\left(\mathrm{Ca}_{2} \mathrm{SiO}_{4}\right)$. This material was chosen to represent an amorphous volcanic material. Volcanic activity has been widespread on Mars, and volcanoclastic deposits have been described (Ehlmann et al., 2011). We decided to use a pure calcium amorphous silicate (rather than a basaltic glass), in order to simplify the chemistry of the system. However, one might expect a more complex chemistry for

142 Martian volcanic glasses. Our approach might appear too simplistic, but might provide grounds 143 for understanding more complex chemistries.

\subsection{Materials}

Portlandite: Calcium hydroxide $\mathrm{Ca}(\mathrm{OH})_{2}$ was provided by Sigma-Aldrich with $96 \%$ chemical purity (about $3 \%$ of $\mathrm{CaCO}_{3}$ ) and $1 \%$ of other impurities. This material is characterized by platy nanoparticles (sheet forms) forming micrometric aggregates with high porosity and/or high specific surface area $\left(15 \mathrm{~m}^{2} / \mathrm{g}\right)$. Its infrared spectrum has revealed a small amount of adsorbed water at atmospheric conditions, around $0,01 \mathrm{gH}_{2} \mathrm{O} / \mathrm{gCa}(\mathrm{OH})_{2}$ determinated by TGA. The portlandite sample was used without any physicochemical treatment.

152 Brucite: Magnesium hydroxide $\mathrm{Mg}(\mathrm{OH})_{2}$ was provided by Fisher Scientific (UK). This material 
153 is characterized by platy hexagonal microparticles. A small amount of adsorbed water at 154 atmospheric conditions was detected by infrared spectroscopy. The brucite sample was crushed in 155 a mortar before use.

156 Amorphous calcium silicate hydrate: This material was synthesized from synthetic larnite 157 mineral $\left(\mathrm{Ca}_{2} \mathrm{SiO}_{4}\right)$ by using a simple acidic treatment $(2 \mathrm{M} \mathrm{HCl}$ solution) at room lab temperature 158 during 15 minutes. Then, consecutive dilutions with demineralized water were carried out until $159 \mathrm{pH}$ equal to 3 . Finally, the solid was separated from the solution by centrifugation (10 minutes at $16012000 \mathrm{rpm}$ ) and dried directly in the centrifugation flasks at $80^{\circ} \mathrm{C}$ for $48 \mathrm{~h}$. The larnite synthetic 161 mineral was provided by A. Santos and it was synthesized as reported in Santos et al. (2009).

162 Carbon dioxide: Carbon dioxide $\mathrm{CO}_{2}$ was provided by Linde Gas S.A. with $99.995 \%$ of 163 chemical purity. This gas was directly injected in the cryogenic reaction cell without any 164 treatment or purification.

\subsection{Infrared microscope}

166 An infrared microscope (BRUKER HYPERION 3000) coupled with a cryogenic cell (designed 167 and built at IPAG) was used to obtain infrared spectra in transmission mode. The IR beam was 168 focused trough a $15 x$ objective and the typical size of the spot on the sample was around 50x50 $169 \mu \mathrm{m}^{2}$. The spectral resolution was $4 \mathrm{~cm}^{-1}$ and the spectra were recorded in transmission mode 170 between $4000 \mathrm{~cm}^{-1}$ and $700 \mathrm{~cm}^{-1}$.

\section{2.3. Cryogenic cell}

172 An environmental cell was designed and built at IPAG in order to simulate low $\mathrm{CO}_{2}$ pressure and 
173 low temperature (LP-LT) close to Martian atmospheric conditions. A heating resistance coupled 174 to a liquid $\mathrm{N}_{2}$ circuit $\left(77 \mathrm{~K}\right.$ ) allows an efficient regulation of sample temperature from $-180^{\circ} \mathrm{C}$ to $175+100^{\circ} \mathrm{C}$. Additionally, a turbomolecular vacuum pump and $\mathrm{CO}_{2}$ cylinder were connected to 176 reach a secondary vacuum and to inject a controlled $\mathrm{CO}_{2}$ pressure into the reaction cell, 177 respectively. Figure 1 shows a schematic diagram of all main parts of the IR-CryoCell setup.

\section{2.4. Gas-solid carbonation experiments}

179 For these measurements, the reacting $\mathrm{Ca}(\mathrm{OH})_{2}$ particles, stored at atmospheric conditions, were 180 manually deposited and compressed as a thin film on a $\mathrm{KBr}$ window. Then the $\mathrm{KBr}$ window was 181 carefully placed in the reaction cell to be assembled to the microscope. All carbonation 182 experiments have been carried out in presence of molecular water (adsorbed or crystallized as ice 183 depending on the carbonation temperature) which catalyze the carbonation process. The 184 carbonation temperatures used in this study were $-10,0,10,25$ or $30^{\circ} \mathrm{C}$ and the $\mathrm{CO}_{2}$ pressures 185 were typically 100, 1000 and 2000 mbar. This pressure is higher than Martian pressure to 186 accelerate the reaction due to a daily timescale limitation by the experimental setup. We note that 187 the $\mathrm{CO}_{2}$ gas has been directly injected into the reaction cell in presence or absence of atmospheric 188 air. For the latter case, we started by fixing the water adsorbed onto the solid by cooling the cell 189 at $-60^{\circ} \mathrm{C}$ before making a high vacuum pumping for $10 \mathrm{~min}$ in order to remove exclusively the air 190 from the reaction cell. After injection of $\mathrm{CO}_{2} 10$ to 15 infrared spectra have been collected as a 191 function of time until an apparent spectroscopic equilibrium state is reached (3-6h).

192 Complementary carbonation experiments have been carried out by using Mg hydroxide (brucite:

$\left.193 \mathrm{Mg}(\mathrm{OH})_{2}\right)$ and the amorphous calcium silicate hydrate as solid reactants, but, for these cases the 194 carbonation temperature has been fixed at $25^{\circ} \mathrm{C}$ and 1 bar of $\mathrm{CO}_{2}$ has been injected into the 
reaction cell without air removal (more reacting system).

Each carbonation experiment has been repeated 2 times in order to verify its reproducibility. All carbonation experiments and their physicochemical conditions are summarized in Table 1.

\subsection{Calculation of integrated band intensities}

The gas-solid carbonation of calcium hydroxide at low temperature $\left(<30^{\circ} \mathrm{C}\right)$ in presence of adsorbed water can be expressed by a global reaction as follows:

$\mathrm{Ca}(\mathrm{OH})_{2}(\mathrm{~s})+\mathrm{CO}_{2}(\mathrm{~g})=>\mathrm{CaCO}_{3}(\mathrm{~s})+\mathrm{H}_{2} \mathrm{O}(\mathrm{v}-\mathrm{l})$

202 Generally, this global reaction is incomplete due to the formation of a protective carbonate layer around the reacting particle which restricts or stops the $\mathrm{CO}_{2}$ transfer at the grain or aggregate scale (Montes-Hernandez et al., 2010a). In the present study, the integrated band intensities for hydroxyl (-OH), carbonate $\left(\mathrm{CO}_{3}{ }^{2-}\right)$ and $\mathrm{H}_{2} \mathrm{O}$ functional groups, concerning reaction (1) at an instant $t$ have been estimated by using a Trapezoidal rule integration. A wavenumber interval and a characteristic continuum have been manually defined to determine the intensity of a given band depending on the initial reactant. For example, in the gas-solid carbonation experiments with $\mathrm{Ca}(\mathrm{OH})_{2}$ particles, two continuums have been defined as linear segments over two different spectral ranges, one for the $-\mathrm{OH}$ at $3640 \mathrm{~cm}^{-1}$ and $\mathrm{H}_{2} \mathrm{O}$ at $3450 \mathrm{~cm}^{-1}$ band intensities and the other

211 for the $\mathrm{H}_{2} \mathrm{O}$ at $1650 \mathrm{~cm}^{-1}$ and $\mathrm{CO}_{3}{ }^{2-}$ at $1420 \mathrm{~cm}^{-1}$ band intensities (see Figure 2).

\subsection{Fitting of the kinetic experimental-calculated data for gas-solid carbonation}

214 Several kinetic models (first-order, pseudo-first-oder, second-order, pseudo-second-order, 215 reversible one, irreversible one...) are generally used for fitting kinetic experimental data of 216 sorption and adsorption systems ( Ho and McKay, 1999; Ho, 2006). For our experiments, we 10 
have chosen pseudo-second-order model because it was successfully applied in previous studies

218 (Montes-Hernandez and Geraud, 2004 ; Montes-Hernandez and Rihs, 2006; Montes-Hernandez 219 et al., 2009, 2010a, 2010b, 2012a, 2012b ) and can be adequately used to fit experimental data of 220 carbonation process as demonstrated in Montes-Hernandez et al., 2009. This model reproduces a 221 process consisting of a fast mass transfer followed by a second step of slower mass transfer until 222 equilibrium is achieved. It can be written in its differential form as follows:

$$
\frac{d A^{C O 3},{ }_{t}}{d t}=K c\left(A^{C O 3},{ }_{\max }-A^{C O 3},{ }_{t}\right)^{2}
$$

224 Where $\mathrm{A}^{\mathrm{CO} 3}{ }_{t}$ is the integrated band intensity for the carbonate group at a given time, $t$ [minutes], 225 corresponding to carbonation extent; $\mathrm{A}^{\mathrm{CO} 3}{ }_{\text {, }}$ ax is the maximum extend of carbonation at 226 equilibrium; $\mathrm{Kc}$ is the rate constant of $\mathrm{Ca}(\mathrm{OH})_{2}$ carbonation.

227 The second step (until equilibrium) is interpreted by as a passivation effect due to the formation 228 of a protective carbonate layer (Montes-Hernandez et al., 2012a). In this study, the increase of 229 integrated band intensity with time for the carbonate group $\left(\mathrm{CO}_{3}{ }^{2-}\right)$, i.e. during gas-solid 230 carbonation process, has been fitted by using a kinetic double-pseudo-second-order model. This 231 model assumes two kinetic regimes due to the presence of two types of reactive surface sites. The 232 integrated form of the double kinetic model is given by the following hyperbolic equation:

$$
A^{C O 3}, t=\frac{\left(A^{C O 3},{ }_{\text {max } 1}\right) t}{\left(t_{1 / 2}+t\right)}+\frac{\left(A^{C O 3},{ }_{\text {max } 2}\right) t}{\left(t_{1 / 2}+t\right)}
$$

234 Where $\mathrm{A}^{\mathrm{CO} 3}{ }_{\mathrm{t}}$ is the integrated band intensity for the carbonate group at a given time, $t$ [minutes], 
235 corresponding to carbonation extent; $\mathrm{A}^{\mathrm{CO} 3},{ }_{\max 1}$ and $\mathrm{A}^{\mathrm{CO} 3},{ }_{\max 2}$ are the maximum extent of 236 carbonation at apparent equilibrium for both kinetic carbonation regimes, respectively; $t_{1 / 2_{1}}$ and $237 t_{1 / 2_{2}}$ are the half-carbonation times for both kinetic carbonation regimes, respectively. In other 238 terms, the half-carbonation times represent the times after which half of the maximum of kinetic 239 carbonation regimes (expressed as maximum of integrated band intensities for carbonate group) 240 is obtained. The fitting of kinetics data allow an estimation of these parameters and was 241 performed by a non linear regression by least-squares method. These simple parameters are used 242 in this study to evaluate the kinetic effects of temperature, $\mathrm{CO}_{2}$ pressure and nature of the solid 243 on the gas-solid carbonation process.

244 The activation energy (Ea, Table 1) of the reaction was calculated assuming an Arrhenius 245 behavior for the initial carbonation rate. We have used 4 points to calculate Ea for carbonation 246 experiments of portlandite (at the temperature of $-10^{\circ} \mathrm{C}, 0^{\circ} \mathrm{C}, 10^{\circ} \mathrm{C}$ and $30^{\circ} \mathrm{C}$, for both experiments 247 performed under 1 bar and 2 bar $\mathrm{CO}_{2}$ ).

\section{3. Results}

251 3.1. Gas-solid carbonation of $\mathrm{Ca}(\mathrm{OH})_{2}$ particles at low temperature $\left(<0^{\circ} \mathrm{C}\right)$

252 Very few experimental studies have characterized the carbonate formation or $\mathrm{CO}_{2}$ mineralization 253 at the mineral-ice water- $\mathrm{CO}_{2}$ interfaces on Earth and planetary cold-environments (e.g. Antarctic 254 and Mars surface). In our study, several gas-solid reactions carried out in the cryogenic cell 255 coupled to the infrared microscope reveal that carbonate formation or $\mathrm{CO}_{2}$ mineralization is 256 possible at low temperature $\left(-10^{\circ} \mathrm{C}\right.$ and $\left.0^{\circ} \mathrm{C}\right)$ using a simplified analogue $\mathrm{Ca}(\mathrm{OH})_{2}($ mineral $)$ - 
water(adsorbed)- $\mathrm{CO}_{2}$ (gas) system (see Fig. 3 (c) to (f)). The results displayed in Figure 3 also order model.

\section{3.2. Gas-solid carbonation of Mg hydroxide}

278 The gas-solid carbonation depends also on the nature of the solid. For this reason one other 13 
279 powdered material, $\mathrm{Mg}$ hydroxide (synthetic brucite), was investigated specifically at higher 280 reactive conditions $\left(25^{\circ} \mathrm{C}\right.$ and 1 bar of $\mathrm{CO}_{2}$, in presence of air). To form $\mathrm{Mg}$ carbonates, the most 281 simple materials as starting reactant are binary oxides or hydroxides in the precursor material. 282 Brucite particles are found to be only slightly carbonated at these $\mathrm{T}-\mathrm{P}_{\mathrm{CO} 2}$ conditions after $5.5 \mathrm{~h}$ of $\mathrm{Mg}(\mathrm{OH})_{2}-\mathrm{CO}_{2}$ interaction (see Figure 7). These in-situ infrared measurements clearly reveal that the $\mathrm{Mg}$ hydroxide (brucite) is more chemically stable than Ca hydroxide (portlandite) under a $\mathrm{CO}_{2}$-rich atmosphere at a given relative humidity. In summary, the gas-solid carbonation of $\mathrm{Ca}$ and $\mathrm{Mg}$ hydroxides depends on the experimental conditions employed (i.e. $\mathrm{T}, \mathrm{P}_{\mathrm{CO} 2}$, relative humidity) and on the intrinsic properties of solid (i.e. hydrophilicity, particle size, specific surface 288 area, and chemical stability).

289 Finally, a kinetic regime and the maximum carbonation extent at an apparent equilibrium $290\left(\mathrm{~A}^{\mathrm{CO} 3},{ }_{\max 1}+\mathrm{A}^{\mathrm{CO} 3},{ }_{\max 2}\right)$ is successfully determined by using a kinetic double-pseudo-second-order 291 model (see Fig. 7 (c)).

\section{3.3. Gas-solid carbonation of an amorphous calcium silicate hydrate}

293 A last materials, an amorphous calcium silicate hydrate, has been investigated at higher reactive 294 conditions $\left(25^{\circ} \mathrm{C}\right.$ and 1 bar of $\mathrm{CO}_{2}$, in presence of air) to test the gas-solid carbonation efficiency.

295 The amorphous calcium silicate hydrate, is significantly carbonated via gas-solid carbonation at 296 the above mentioned T- $\mathrm{P}_{\mathrm{CO} 2}$ conditions after $8 \mathrm{~h}$ of reaction (see Figure 8), which suggests 297 chemical stability has a significant impact on the efficiency of the carbonation.

298 Finally, a kinetic regime and the maximum carbonation extent at apparent equilibrium $\left(\mathrm{A}^{\mathrm{CO} 3}{ }_{\max 1}\right.$ $299+\mathrm{A}^{\mathrm{CO} 3}{ }_{\max 2}$ ) is also successfully determined by using the kinetic double-pseudo-second-order 300 model (see Fig. 8 (c)). 


\section{The mechanism of carbonation}

303 All the experiments with the $\mathrm{Ca}$ and $\mathrm{Mg}$ hydroxides show an increase of the band intensities of carbonates, at low temperature and low pressure. In this study we assume that part of the water

305

306

307

308 initially adsorbed onto $\mathrm{Ca}(\mathrm{OH})_{2}$ particles was partially crystallized by cooling when the temperature is negative $\left(<0^{\circ} \mathrm{C}\right)$. The presence of an ice layer limits the access of $\mathrm{CO}_{2}$ molecules to nanopores, and therefore limiting the $\mathrm{CO}_{2}$ access to the local $\mathrm{CO}_{3}{ }^{2-}$ production $\left(\mathrm{CO}_{2}(\mathrm{~g})+\mathrm{H}_{2} \mathrm{O}(\right.$ adsorbed $\left.)=>\mathrm{CO}_{3}{ }^{2-}+2 \mathrm{H}^{+}\right)$required to form a carbonate layer around the $\mathrm{Ca}(\mathrm{OH})_{2}$ particles (see also: Montes-Hernandez et al. 2010a). Strictly speaking, the relative humidity is not controlled in our experiments; however, two experiment protocols implying atmospheric vapor have been designed, firstly, direct injection of $\mathrm{CO}_{2}$ gas into the reaction cell initially filled with air, i.e. at lab relative humidity $\left(\mathrm{CO}_{2}\right.$-air system) and secondly, the injection of $\mathrm{CO}_{2}$ gas after removal of the air by secondary vacuum pumping at low temperature $\left(-60^{\circ} \mathrm{C}\right)\left(\mathrm{CO}_{2}\right.$ system $)$. The difference between these experiments could explain why the carbonation extent decreases when the initial air (contained into the reaction cell) is removed (see comparisons (c) and (d) or (e) and (f) in Fig. 3). We can assume a similar relative humidity of the lab room for all experiments. The relative humidity has clearly an impact on the carbonation efficiency, the experiments without air (very low relative humidity) showing a lower amount of carbonation at low temperature.

The fit of the data by the kinetic model assumes two kinetic regimes, usually due to the presence of two types of reactive surface sites. In our carbonation experiments, the formation of a hydrated carbonate layer around the core of reacting $\mathrm{Ca}(\mathrm{OH})_{2}$ particles produces a complex passivation step, possibly perturbed by three simultaneous physicochemical processes: (1) solid state transformation from hydrated calcium carbonate to calcite and/or from aragonite to calcite, (2) partial expelling of produced molecular water during the carbonation process (see Eq. (1)) and (3) 15 
325 local acidification by an excess of molecular water in pores or onto surfaces $\left(\mathrm{H}_{2} \mathrm{O}\right.$ (produced)+ $\left.326 \mathrm{CO}_{2}(\mathrm{~g})=>\mathrm{HCO}_{3}^{-}+\mathrm{H}^{+}\right)$. In summary, the complex kinetic behavior related to gas-solid 327 carbonation of $\mathrm{Ca}(\mathrm{OH})_{2}$ particles is successfully described applying two kinetic regimes. A 328 schematic representation of this carbonation process is illustrated in Figure 9. The rate of 329 carbonation depends on the access to the nanopores of the material by the $\mathrm{CO}_{2}$. These pores have 330 to be water-unsaturated to facilitate access of the $\mathrm{CO}_{2}$ gas to react with the minerals. The pressure 331 has a strong impact on the rate and yield of carbonation. In the case of the low pressure experiments, a two stage kinetic model was shown to fit the data. Experiments revealed a fast carbonation during a short time (stage 1) followed by a slower carbonation (stage 2). The 334 magnitude of carbonate formation is high in stage 1 and lower in stage 2 . In the case of the 335 experiments performed at higher $\mathrm{CO}_{2}$ pressure (2 bar) (fig. 6.c) a two stage reaction is also 336 observed. However, unlike the low pressure experiments, the magnitude of carbonation achieved 337 in stage 2 is quite significant.

338 For the low pressure experiments, we suspect that the intraparticle diffusion of $\mathrm{CO}_{2}$, possibly 339 limited by the low gas pressure in the system $\left(100\right.$ mbar of $\left.\mathrm{CO}_{2}\right)$, is the rate limiting step due to 340 the carbonate layer which strongly reduce the diffusion of the gas. This rate limiting step is no 341 more observed at high $\mathrm{CO}_{2}$ pressure ( $>20$ bar). In this case, the $\mathrm{Ca}(\mathrm{OH})_{2}$ particles are completely 342 carbonated, leading to the formation of calcite nano-crystals (Montes-Hernandez et al., 2010b). 343 We can assume a correlation between the pressure and the thickness of the layer that transforms 344 to carbonate by gas-solid reaction. The effect of $\mathrm{CO} 2$ pressure observed in explained by the 345 presence of passivation step and the formation of carbonate layer through which $\mathrm{CO} 2$ molecules 346 have to diffuse. Therefore in the case of an uncarbonated material, the effect of $\mathrm{CO}_{2}$ pressure on 347 the initial reaction rate is expected to be moderate. Although the $\mathrm{CO}_{2}$ pressure on Mars (about 10 16 
mbar) is lower than $\mathrm{CO}_{2}$ pressures used in our experiments (100 mbar), it is likely that our results can be extrapolated to Martian atmospheric $\mathrm{CO}_{2}$ pressure.

Unfortunately, the gas-solid carbonation mechanism of amorphous calcium silicate hydrate is not elucidated due to its unknown atomic organization. However, we assume that the abundant molecular water adsorbed onto the solid plays a crucial role to start the gas-solid carbonation process at the investigated conditions. The in-situ infrared measurements reveal two important insights: (1) The expelling of pre-existent molecular water in/on the solid towards the gas phase during the carbonation process. This is attested by a clear decrease of the stretching and bending band intensities of water (see Fig. 8 (a) and (b)), (2) Similar to carbonation of Ca hydroxide, the formation of calcite and aragonite are mainly identified, the formation of hydrated calcium carbonate being only suspected (see also Montes-Hernandez et al. 2010a)

\section{Discussion}

$$
\text { Carbonates have been found on Mars in two kinds of geological settings: (i) outcrops of }
$$
carbonates, identified in the Nili Fossae region (Ehlmann et al., 2008), in the central peak of Leighton crater (Michalski and Niles, 2010) and in the Columbia Hills of Gusev crater (Morris et al., 2010); and (ii) carbonates-bearing dust, identified by the TES instrument (Bandfield et al., 2003) and the phoenix lander (Boynton et al., 2009). In the case of the outcrops from the Columbia Hills and Nili Fossae, carbonates are present as major components (16 to 34 wt \% in the case of the Columbia Hills, about $80 \%$ in the case of Nili Fossae), and their derived 17 
371 chemistry is similar to that of carbonates found in Martian meteorites (Mittlefehldt, 1994), i.e.

372 Fe-Mg carbonates. The association of these carbonate outcrops with phyllosilicates advocate for a 373 possible hydrothermal origin of these carbonates, a phenomenon that has been reproduced in 374 laboratory experiments (Golden et al., 2000) and that is observed in some terrestrial hydrothermal 375 systems (Treiman et al., 2002; Brown et al., 2010). However, it is well known that terrestrial 376 alteration of mafic rocks can produce brucite as a primary alteration product (Xiong and Snider 377 Lord, 2008), which should readily transform into carbonate by interaction with the Martian 378 atmosphere, according to our experiments. The observed carbonates outcrops could rather be 379 former outcrops of brucite-rich sedimentary rocks, that were subsequently altered to carbonates 380 by interaction with the atmosphere.

381 In the case of carbonates observed in the Martian dust, both magnesite (Bandfield et al., 2003) 382 and calcite (Boynton et al., 2009) have been reported, and their typical abundance is below $5 \%$. 383 Although aqueous formation has received widespread attention for this type of occurrence of 384 carbonates on Mars, we propose gas-solid reaction as a possible formation mechanism. Calcite 385 formation at the dust- $\mathrm{CO}_{2}$ interfaces requires a source of calcium (e.g. Ca binary oxides or an 386 amorphous metastable Ca silicate) possibly coming from volcanic activity (Shaheen et al., 2010), 387 mechanical erosion or extra-Martian particulate matter (including meteorite impacts, interstellar 388 dusts). A large diversity of phyllosilicates and hydrated phyllosilicates was found on the Martian 389 surface (Mustard et al., 2008; Jänchen et al., 2006; Fairén et al., 2009; Murchie et al., 2009; 390 Ehlmann et al., 2011). As we have shown, the presence of molecular water is also required 391 because hydration of the Ca precursor is assumed to be a crucial step prior to the carbonation 392 process. Laboratory studies of Martian analogs suggest that adsorbed water should be present in 393 significant amount within the Martian soil (Pommerol et al., 2009; Beck et al., 2010; Jänchen et 18 
394 al., 2006) and adsorbed water has been also detected by infrared spectroscopy (Poulet et al., 395 2009). In addition, the gamma rays and neutrons spectrometers on Mars Odyssey have shown 396 evidence for the presence of water in the first meter of the martian subsurface (Feldman et al., 397 2004). A simplified scenario for calcite formation at the dust- $\mathrm{CO}_{2}$ interfaces and its natural 398 deposition on the soil is schematically illustrated in Fig. 10. In this scenario we assume that the 399 precursor, a calcium hydroxide with adsorbed water, is produced by atmospheric alteration of 400 volcanic $\mathrm{CaO}$ particles in the atmosphere. Reactant minerals such as portlandite could be difficult 401 to detect on Mars by reflectance spectroscopy due to the carbonate layer around the calcium 402 hydroxide. In the case of hydromagnesite, the presence of brucite is required somewhere on 403 Mars, which would be subsequently transformed to carbonates, eroded, and transported. As we 404 stated earlier, brucite should form in association with phyllosilicates during the aqueous alteration 405 of mafic rocks.

406 The efficiency of carbonates synthesis on Mars by gas-solid reaction will depend on the 407 mineral substrate (as we showed, brucite, portlandite and larnite have distinct synthesis kinetics), 408 the local temperature, the atmospheric humidity, and likely the atmospheric pressure (which can 409 substantially vary with season as well as with topography). Even at temperatures below the frost 410 point, carbonates synthesis can occur by gas-solid reaction, on a daily timescale (table 1). On 411 Mars, the water vapor pressure is low $\left(\mathrm{P}_{\mathrm{H} 2 \mathrm{O}}\right.$ about $\left.10 \mathrm{~Pa}\right)$ and the frost point is depressed with 412 regard to that on Earth. Given the present knowledge of the water vapor surface pressure, a 413 typical value of $200 \mathrm{~K}$ is found for the frost point on the Martian surface (Schorghofer and 414 Aharonson., 2005). Such temperature typically corresponds to seasonal average around $60^{\circ}$ in 415 latitude.

416 The relative humidity on Mars fluctuates on a daily basis. At the Phoenix landing site (Smith P.H. 19 
et al., 2009) it is measured around 5\% during Martian day time, close to saturation early night

418 and saturating at the end of the night. Carbonate synthesis will be accelerated by a high

419 atmospheric humidity, which can occur during the warmer season. TES instrument on Mars

420 Global Surveyor has water vapor evolution during 2 martian years, and the maximum was found

421 during midsummer in the northern hemisphere with $100 \mathrm{pr}-\mu \mathrm{m}$ (Smith M.D., 2002,2004). The

422 maximum water vapor measured by Mars Express instruments (OMEGA and SPICAM) is found

423 during midsummer, around $60 \mathrm{pr}-\mu \mathrm{m}$ content. This maximum is observed at latitude $75-80^{\circ} \mathrm{N}$

424 and longitudes 210-240 E (Fouchet et al., 2007; Fedorova et al., 2006; Melchiorri et al.,2007)),

425 an area is close to Phoenix landing site (latitude $68^{\circ} \mathrm{N}$ and longitude $233^{\circ} \mathrm{E}$ ).

426 Current Global Circulation Models (GCM) of Mars can be used to determine the optimal

427 locations and times for the gas-solid synthesis of carbonates. Simulations with Mars Climate 428 Database (Forget et al., 1999, 2006) estimated high relative humidity (around 70\%) and 429 temperatures close to $-20^{\circ} \mathrm{C}$ during mid summer $\left(\mathrm{L}_{\mathrm{s}}=120^{\circ}\right)$ in the Phoenix landing site area (at 12 430 a.m). These conditions are sufficient to initiate the carbonation reaction according to our 431 experiments, and carbonates were observed in the Phoenix soil (Smith et al., 2009)

Mars is not the only extra-terrestrial body where carbonates have been detected, this is

434 also the case of Ceres, the largest asteroid in the main belt. Its shape is close to hydrostatic 435 equilibrium and its bulk density suggests the presence of ice in its interior (Thomas et al., 2005).

436 The surface of Ceres shows a well-resolved 3- $\mu \mathrm{m}$ absorption band, which interpretation has been 437 debated (Lebofsky et al., 1981; Vernazza et al., 2005; Rivkin et al., 2006; Rivkin et al., 2011; 438 Beck et al., 2011). In a recent study, Milliken and Rivkin (2009) combined NIR and MIR 439 observations of Ceres' surface and successfully modeled both spectral regions with a combination 20 
440 of brucite, carbonate and a Fe-rich phyllosilicate. Such a mineralogical assemblage was explained

441 by aqueous alteration of mafic silicates in the presence of $\mathrm{CO}_{2}$, by analogy with the processes

442 inferred from the mineralogy of hydrated meteorites that can present a significant amount of

443 carbonates (Zolensky et al., 2002). If brucite is rare in the mineralogy of hydrated chondrites, it is

444 a common product of aqueous alteration of terrestrial rocks. The condition of brucite formation is

445 specific in terms of $\mathrm{T}, \mathrm{pH}$ and $\mathrm{pO}_{2}$, and source rock. If the formation of carbonate by reaction of

446 brucite with water is possible, gas-solid reaction cannot be excluded. This mechanism could

447 occur at some depth in the asteroid body, where $\mathrm{CO}_{2}$ pressure can build-up. However, because of

448 the low temperature at the surface of Ceres, long timescales are expected for such a process.

449 Further consideration would require an accurate knowledge of the kinetics of the gas-solid 450 carbonation.

Finally, the carbonate synthesis mechanism that we described is certainly active on Earth, where carbonate minerals played an important role in the planet evolution. Many studies are available about carbonate reactivity and synthesis in liquid-water but information on its behavior at sub-zero temperatures (for example solubility in frozen water) are sparse. The results we obtained reveal that gas-solid carbonation can occur at sub-zero temperature, in the presence of gaseous $\mathrm{CO}_{2}$ and $\mathrm{H}_{2} \mathrm{O}$. These conditions are present on Earth in arctic regions and in the upper atmosphere. This mechanism can thus occur on the availability of the adequate precursor.

The presence of oxygen isotope anomalies in carbonates from terrestrial aerosols 460 (Shaheen et al., 2010) suggests a carbonation by exchange with ozone. Such a result suggests a 461 possible formation of carbonate by chemical reaction in the upper atmosphere, from a $\mathrm{CaO}$

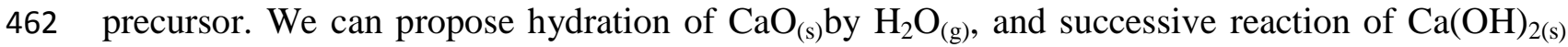
21 

471 adequate precursor (as we showed here, an $\mathrm{Ca}$ or $\mathrm{Mg}$ hydroxides, or $\mathrm{Ca}$-rich amorphous 472 silicates).

\section{3}

474

with $\mathrm{CO}_{2(\mathrm{~g})}$ as a formation mechanism of these carbonates.

Calcium carbonate and carbonate hydrates have been found in arctic ice (Dieckmann et al., 2008; Sala et al. 2008). The formation mechanism of these carbonates is a matter of active research, since it could provide a major $\mathrm{CO}_{2}$ sequestration process. Hydrous carbonates (for instance ikaite) have been proposed to originate by precipitation during sea-ice formation, as suggested by thermodynamical calculations. Anhydrous carbonates can have an origin as primary aerosols, with a synthesis mechanism possibly similar to the one described in the previous paragraph. In addition, in situ gas-solid formation is possible, depending on the availability of an

\section{Conclusion}

In this study, we designed an original experimental method to form carbonates via gas-solid reaction in presence of adsorbed water. We used an infrared microscope coupled to a cryogenic reaction cell (IR-CryoCell setup) to investigate this process with 3 different carbonate precursors (Ca hydroxide (portlandite), Mg hydroxide (brucite), and an amorphous calcium silicate hydrate). We demonstrated for the first time that calcium carbonate can be formed at low temperature $\left(<0^{\circ} \mathrm{C}\right)$ via gas solid carbonation of $\mathrm{Ca}$ hydroxide. Both amorphous $\mathrm{Ca}$ silicate hydrate and $\mathrm{Ca}$ hydroxide were significantly carbonated at the investigated $\mathrm{T}-\mathrm{P}_{\mathrm{CO} 2}$ conditions. Conversely, only a very slight gas-solid carbonation of Mg hydroxide particles was detected by IR spectroscopy. We extracted the kinetic parameters of the reaction from our measured carbonation curves, following

44 a kinetic double-pseudo-second-order model. From these results we can clearly state that the conditions for gas-solid carbonation exist on Mars, and that this process could be the source of 22 
the detected $\mathrm{Ca}$ and $\mathrm{Mg}$ carbonates found in the Martian dust and soil. These carbonates can be synthesized from a brucite precursor (a common hydrothermal product), from volcanic derived 488 aerosols, as well as from extraterrestrial dust. This mechanism should be considered in future 489 global modeling of the carbon cycle of the red planet, and might also be active in cold terrestrial 490 deserts.

491

492

\section{Acknowledgements}

493 The authors are grateful to the French National Center for Scientific Research (CNRS), the 494 French National Research Agency (ANR) and University Joseph Fourier (UJF) in Grenoble for 495 providing the financial support.

\section{References}

Bandfield, J.L., Glotch, T.D. and Christensen, P.R., 2003. Spectroscopic Identification of Carbonate Minerals in the Martian Dust. Science. 301, 1084-1087.

Beck, P., Pommerol, A., Schmitt, B. and Brissaud, O., 2010. Kinetics of water adsorption on minerals and the breathing of the Martian regolith. J.Geophys. Res.-Planets. 115, E10011

Beck, P., Quirico, E., Sevestre, D., Montes-Hernandez, G., Pommerol, A. and Schmitt, B. 2011. Goethite as an alternative origin of the $3.1 \mathrm{mu} \mathrm{m}$ band on dark asteroids. Astron. Astrophys. 526, A85.

Baltrusaitis, J. and Grassian, V.H., 2005. Surface reactions of carbon dioxide at the adsorbed water-iron oxide interface. J Phys Chem B. 109, 12227-12230. 
Boynton, W. V., Ming, D. W., Kounaves, S. P., Young, S. M. M., Arvidson, R. E., Hecht, M. H.,

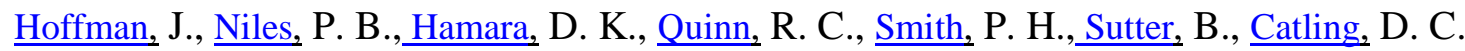
and Morris, R. V., 2009 Evidence for Calcium Carbonate at the Mars Phoenix Landing Site. Science. 325, 61-64. potential of olivine and orthopyroxene. J. Petrol. 49, 1873-1887.

527 Fairén, A. G., Fernandez-Remolar, D., Dohm, J. M., Baker, V. R. and Amils, R., 2004. Inhibition 
of carbonate synthesis in acidic oceans on early Mars. Nature. 431, 423-426.

529 Fairén, A.G., Davila, A.F., Gago-Duport, L., Amils, R. and McKay, C.P., 2009. Stability against 530 freezing of aqueous solutions on early Mars. Nature.459,401-404.

531 Fedorova, A., Korablev, O., Bertaux, J.-L., Rodin, A., Kiselev, A. and Perrier, S., 2006. Mars water vapor abundance from SPICAM IR spectrometer: Seasonnal and geographic distributions. J. Geophys. Res.111, E09S08.

534 Feldman, W.C., Prettyman, T.H., Maurice, S., Plaut, J.J., Bish, D.L., Vaniman, D.T., Mellon, Funsten, H.O. Lawrence, D.J. and Tokar, R.L., 2004. Global distribution of near-surface hydrogen on Mars. J. Geophys. Res.109, E09006.

Forget, F., Hourdin, F., Fournier, R., Hourdin, C., Talagrand, O., Collins, M., Lewis, S. R., Read, P. L., \& Huot, J.-P. 1999. Improved general circulation models of the Martian atmosphere from the surface to above $80 \mathrm{~km}$. Journal of Geophysical Research, 1042, 24155-24176.

Forget, F., Millour, E., Lebonnois, S., Montabone, L., Dassas, K., Lewis, S. R., Read, P. L., López-Valverde, M. A., González-Galindo, F., Montmessin, F., Lefèvre, F., Desjean, M.C., \& Huot, J.-P. 2006 (Feb.). The new Mars climate database. Page 128 of : F. Forget, M. A. Lopez-Valverde, M. C. Desjean, J. P. Huot, F. Lefevre, S. Lebonnois, S. R. Lewis, E. Millour, P. L. Read, \& R. J. Wilson (ed), Mars Atmosphere Model ling and Observations.

Fouchet, T., Lellouch, E., Ignatiev, N.I., Forget, F., Titov, D.V., Tschimmel, M., Montmessin, F., Formisano, V., Guiranna, M., Maturilli, A. and Encrenaz, T., 2007. Martiann water vapor: Mars Express PFS/LW observations. Icarus. 190, 32-49.

Gail, H.-P. and Sedlmayr, E., 1999. Mineral formation in stellar winds. Astron. Astrophys. 347, $594-616$. 
551 Galhotra, P., Navea, J.G., Larsen, S.C. And Grassian,V.H. , 2009. Carbon dioxide ((CO2)-O-16 and (CO2)-O-18) adsorption in zeolite Y materials: Effect of cation, adsorbed water and particle size. Energ Environ Sci .2,401-409.

554 Golden, D. C., Ming, D. W., Schwandt, C. S., Morris, R. V., Yang, S. V. and Lofgren, G. E., 2000. An experimental study on kinetically-driven precipitation of calcium-magnesiumiron carbonates from solution: Implications for the low-temperature formation of carbonates in martian meteorite Allan Hills 84001. Meteoritics Planet. Sci. 35, 457-465.

Ho, Y.S. and McKay, G., 1999. Pseudo-second order model for sorption processes. Process Biochem. 34, 451-465

Ho, Y.S., 2006. Review of second order models for adsorption systems. J. Hazard Mater. B136, $681-689$

Jänchen, J., Bish, D.L., Möhlmann, D.T.F. and Stach, H., 2006. Investigation of the water sorption properties of Mars-relevant micro-and mesoporous minerals. Icarus. 180, 353358.

Lebofsky, L.A., Feierberg, M.A., Tokunaga, A.T., Larson, H.P. and Johnson, J.R., 1981. The 1.7to 4.2-micron spectrum of asteroid 1 Ceres: evidence for structural water in clay minerals. Icarus. 48, 453-459.

Melchiorri, R., Encrenaz, T., Fouchet, T., Drossart, P., Lellouch, E., Gondet, B., Bibring, J.-P., Langevin, Y., Schmitt, B., Titov, D. and Ignatiev, N., 2007. Water vapor mapping on Mars using OMEGA/Mars Express. Planet. Space Sci. 55. 333-342.

Michalski, J. R. and Niles, P. B., 2010. Deep crustal carbonate rocks exposed by meteoritic impact on Mars. Nat. Geosci. 3, 751-755. 
573 Milliken, R.E. and Rivkin, A.S., 2009. Brucite and carbonate assemblage from altered olivinerich materials on Ceres. Nat. Geosci. 2, 258-261.

575 Mittlefehldt, D.W., 1994. ALH84001, a cumulate othopyroxenite member of the Martian meteorite clan. Meteoritics 29, 214-221.

577 Montes-H, G. and Geraud, Y. 2004. Sorption kinetic of water vapour of MX80 bentonite submitted to different physical-chemical and mechanical conditions. Colloid Surface A. $235,17-23$.

Montes-H, G. and Rihs, S. 2006. A simplified method to estimate kinetic and thermodynamic parameters on the solid-liquid separation of pollutants. J. Colloid Interf. Sci. 299, 49-55.

Montes-Hernandez, G., Fernandez-Martinez, A. and Renard, F. 2009. Novel Method to Estimate the Linear Growth Rate of Submicrometric Calcite Produced in a Triphasic Gas-LiquidSolid System. Cryst. Growth Des. 9, 4567-4573.

Montes-Hernandez, G., Pommerol, A., Renard, F., Beck, P., Quirico, E. and Brissaud, O., 2010a. In situ kinetic measurements of gas-solid carbonation of $\mathrm{Ca}(\mathrm{OH})_{2}$ by using infrared microscope coupled to a reaction cell. Chem. Eng. J. 161, 250-56. Calcite through Gas-Solid Carbonation of Nanosized Portlandite under Anisobaric Conditions. Cryst. Growth Des. 10, 4823-4830. $\mathrm{Ca}(\mathrm{OH}) 2$ and $\mathrm{CaO}$ particles under non-isothermal and isothermal conditions by using a 
601

thermogravimetric analyzer: Implications for CO2 capture . Int. J. Greenh. Gas. Con. 11, 4172-180.

Montes-Hernandez, G., Daval, D., Findling, N., Chiriac, R. and Renard, F., 2012b. Linear growth rate of nanosized calcite synthesized via gas-solid carbonation ofCa $(\mathrm{OH}) 2$ particles in a static bed reactor. Chem. Eng. J. 180, 237-244

Morris, R.V., Ruff, S.W., Gellert, R., Ming, D.W., Arvidson, R. E.,Clark, B.C., Golden, D. C., Siebach, K., Klingelhöfer, G., Schröder, C., Fleischer, I., Yen, A.S. and Squyres, S.W., 2010. Identification of Carbonate-Rich Outcrops on Mars by the Spirit Rover. Science $.329,421-424$.

Murchie, S.L., Mustard, J.F. Ehlmann, B.L., Milliken, R.E., Bishop, J.L., McKeown, N.K., Noe Dobrea, E.Z., Seelos, F.P., Buczkowski, D.L., Wiseman, S.M., Arvidson, R.E., Wray, J.J., Swayze, G., Clark, R.N., Des Marais, D.J., McEwen, A.S. and Bibring, J.-P., 2009. A synthesis of Martian aqueous mineralogy after 1 Mars year of observations from the Mars Reconnaissance Orbiter. J.Geophys. Res.114, E00D06.

Mustard, J.F., Murchie, S.L., Pelkey, S.M., Ehlmann, B.L., Milliken, R.E., Grant, J.A., Birbing, J.-P., Poulet, F., Bishop, J., Noe Dobrea, E., Seelos, F., Arvidson, R.E., Wiseman, S., Green, R., Humm, D., Malaret, E., McGovern, J.A., Seelos, K., Clancy, T., Clark, R., Des Marais, D., Izenberg, N., Knudson, A., Langevin, Y., Martin, T., McGuire, P., Robinson, M., Roush, T., Smith, M., Taylor, H., Titus, T. and Wolff, M., 2008. Hydrated silicate minerals on Mars observed by the Mars Reconnaissance Orbiter CRISM instrument. Nature. 454, 305-309

Ochs, D., Braun, B., Maus-Friedrichs, W. and Kempter, V. 1998a. CO2 chemisorption at Ca and 
Ochs, D., Brause, M., Braun, B., Maus-Friedrichs, W. and Kempter V.,1998b. CO2 chemisorp tion at Mg and MgO surfaces: A study with MIES and UPS (He I). Surf .Sci., 397,101107.

Paquette, J. and Reeder, R.J., 1995. Relationship between surface structure, growth mechanism 620 and trace element incorporation in calcite. Geochem.Cosmochem. Acta. 59, 735-749.

Pommerol, A., Schmitt, B., Beck, P. and Brissaud, O., 2009. Water sorption on martian regolith analogs: Thermodynamics and near-infrared reflectance spectroscopy. Icarus. 204, 114136.

Poulet, F., Bibring, J.-P., Langevin, Y., Mustard, J.F., Mangold, N., Vincendon, M., Gondet, B., Pinet, P., Bardintzeff, J.-M. And Platevoet, B., 2009. Quantitative compositional analysis of martian mafic regions using the Mex/OMEGA reflectance data 1.Methodology, uncertainties and examples of application. Icarus. 201, 69-83.

Rivkin, A.S., Volquardsen, E.L. and Clark, B.E., 2006. The surface composition of Ceres: discovery of carbonates and iron-rich clays. Icarus. 185, 563-567

Rivkin, A.S., Li, J.Y., Milliken, R.E., Lim, L.F., Lovell, A.J., Schmidt, B.E., McFadden, L.A. And Cohen, B.A., 2011. The surface composition of Ceres. Space Sci. Rev. 163, 95-116

Sala, M. , Delmonte, B., Frezzotti, M., Proposito, M., Scarchilli, C., Maggi, V., Artioli, G., Dapiaggi, M., Marino, F., Ricci, P.C. and De Giudici, G., 2008. Evidence of calcium carbonates in coastal (Talos Dome and Ross Sea area) East Antarctica snow and firn: Environmental and climatic implications. Earth Planet. Sci. Lett. 271, 43-52. 
Santos, A., Ajbary, M., Morales-Flórez, V., Kherbeche, A., Pĩnero, M. and Esquivias, L., 2009. Larnite powders and larnite/silica aerogel composites as effective agents for $\mathrm{CO} 2$ sequestration by carbonation. J. Hazard. Mater. 168, 1397-1403.

Schorghofer, N. and Aharonson, O., 2005. Stability and exchange of subsurface ice on Mars. J. Geophys. Res. 110, E05003.

Shaheen, R., Abramian, A., Horn, J., Dominguez, G., Sullivan, R. and Thiemens, M. H., 2010. Detection of oxygen isotopic anomaly in terrestrial atmospheric carbonates and its implications to Mars. Proceedings of the National Academy of Sciences of the United States of America 107, 20213-20218.

Sigg, L., Xue, H., Kistker, D. and Schönenberger, R., 2000. Size fractionation (dissolved, colloidal and particulate) of trace metals in the Thur River, Switzerland. Aquat. Geochem. $6,413-434$

Smith, M.D., 2002. The annual cycle of water vapor on Mars as observed by the Thermal Emission Spectrometer. J. Geophys. Res. 107, E11,5115.

Smith, M.D., 2004. Interannual variability in TES atmospheric observations of Mars during 1999-2003. Icarus. 167, 148-165.

Smith, M.D., Wolff, M.J., Clancy, R.T. and Murchie, S.L., 2009. Compact Reconnaissance Imaging Spectrometer observations of water vapor and carbon monoxide. J. Geophys. Res. 114, E00D03.

Smith, P.H., Tamppari, L.K., Arvidson, R.E., Bass, D., Blaney, D., Boynton, W.V., Carswell, A., Catling, D.C., Clark, B.C., Duck, T., DeJong, E., Fisher, D., Goetz, W., Gunnlaugsson, H.P., Hecht, M.H., Hipkin, V., Hoffman, J., Hviid, S.F., Keller, H.U., Kounaves, S.P., 

Site. Science .325, 58-61.

Stumm, W. and Morgan, J.J., 1995. , Aquatic Chemistry - Chemical Equilibria and Rates in Natural Waters, John Wiley \& Sons Inc., Third Edition, New York.

Thomas, P.C., Parker, J.Wm., McFadden, L.A., Russel, C.T., Stern, S.A., Sykes, M.V. and Young, E.F., 2005. Differentiation of the asteroid Ceres as revealed by its shape. Nature. 437, 224-226.

Treiman, A. H., Amundsen, H. E. F., Blake, D. F. and Bunch, T., 2002. Hydrothermal origin for carbonate globules in Martian meteorite ALH84001: a terrestrial analogue from Spitsbergen (Norway). Earth Planet. Sci. Lett. 204, 323-332.

Vernazza, P., Mothé-Diniz, T., Barucci, M.A., Birlan, M., Carvano, J.M., Strazzulla, G., Fulchignoni, M. and Migliorini, A., 2005. Analysis of near-IR spectra of 1 Ceres and 4 Vesta, targets of the Dawn mission. Astron. Astrophys. 436, 1113-1121.

Xiong, Y. and Snider Lord, A., 2008. Experimental investigations of the reaction path in the $\mathrm{MgO}-\mathrm{CO}_{2}-\mathrm{H}_{2} \mathrm{O}$ system in solutions with various ionic strengths, and their applications to nuclear waste isolation. App. Geochem. 23, 1634-1659.

Yamamoto, S., Bluhm, H., Andersson, K., Ketteler, G., Ogasawara, H., Salmeron, M. and Nilsson, A., 2008. In situ X-ray photoelectron spectroscopy studies of water on metals and oxides at ambient conditions. J. Phys. Condens. Matt., 20, 184025184014. 
680

681

682

683

684

685

686

687

688

689

690

691

692

693

694

695

696

697

698

699

700

701

702

98

02
Tonui, E., 2002. Mineralogy of Tagish Lake : An ungrouped type 2 carbononaceous chondrite. Meteorit. Planet. Sci. 37, 737-761.

33

Zolensky, M.E., Nakamura, K., Gounelle, M., Mikouchi, T., Kasama, T., Tachikawa, O. and

1

84

85

86

887

88

89

690

991

92

93

99

95

96

697


703 Table 1. Summary of the experiments with their experimental conditions and the corresponding 704 kinetic parameters determined for gas-solid carbonation.

\begin{tabular}{|c|c|c|c|c|c|c|c|c|}
\hline \multirow[t]{2}{*}{ Exp. } & \multirow[t]{2}{*}{ Starting material } & \multirow[t]{2}{*}{ Gas pressure } & \multirow[t]{2}{*}{ temperature } & \multicolumn{2}{|c|}{$\mathrm{A}^{\mathrm{CO} 3},{ }_{\max 1} \mathrm{~A}^{\mathrm{CO} 3}$} & $i_{\max 2} t_{1 / 2_{1}}$ & $t_{1 / 2_{2}}$ & \multirow{2}{*}{$\begin{array}{l}\mathrm{Ea} \\
(\mathrm{kJ} / \mathrm{mol})\end{array}$} \\
\hline & & & & (a.u.) & $(a, u)$, & \multicolumn{2}{|c|}{ (minutes) } & \\
\hline 1 & portlandite & 2 bar $\mathrm{CO}_{2}$ & $-10^{\circ} \mathrm{C}$ & 1.8 & 4.6 & 19.6 & 599.6 & \\
\hline 2 & portlandite & 2 bar $\mathrm{CO}_{2}$ & $0^{\circ} \mathrm{C}$ & 6.4 & 0.8 & 8.9 & 8.9 & 43 \\
\hline 3 & portlandite & 2 bar $\mathrm{CO}_{2}$ & $10^{\circ} \mathrm{C}$ & 5.3 & 11.4 & 61.8 & 61.8 & \\
\hline 4 & portlandite & 2 bar $\mathrm{CO}_{2}$ & $25^{\circ} \mathrm{C}$ & 29.3 & 54.8 & 2.5 & 126.6 & \\
\hline 5 & portlandite & 1 bar $\mathrm{CO}_{2}+$ air & $-10^{\circ} \mathrm{C}$ & 2.5 & 5 & 3.7 & 33622 & \\
\hline 6 & portlandite & 1 bar $\mathrm{CO}_{2}+$ air & $0^{\circ} \mathrm{C}$ & 5.4 & 10.2 & 6.3 & 28.5 & 75 \\
\hline 7 & portlandite & 1 bar $\mathrm{CO}_{2}+$ air & $10^{\circ} \mathrm{C}$ & 15.8 & 3.1 & 3.5 & 180.1 & \\
\hline 8 & portlandite & 1 bar $\mathrm{CO}_{2}+$ air & $30^{\circ} \mathrm{C}$ & 26 & 21.2 & 3.5 & 5.8 & \\
\hline 9 & portlandite & 100 mbar $\mathrm{CO}_{2}$ & $25^{\circ} \mathrm{C}$ & 19.8 & 10.9 & 0.8 & 419.1 & \\
\hline 10 & brucite & 1 bar $\mathrm{CO}_{2}+\operatorname{air}$ & $25^{\circ} \mathrm{C}$ & 9.5 & 4.8 & 3 & 184.1 & \\
\hline \multicolumn{4}{|c|}{11 Amorphous Ca silicate hydrate 1 bar $\mathrm{CO}_{2}+$ air $25^{\circ} \mathrm{C}$} & 8.9 & 68 & $<0.5$ & 13.6 & \\
\hline
\end{tabular}

Ea was calculated with Arrhenius equation. For experiments with 2 bar $\mathrm{CO}_{2}$,we exclude the point of $10^{\circ} \mathrm{C}$ due to his incoherence with Arrhenius equation.

705

706 


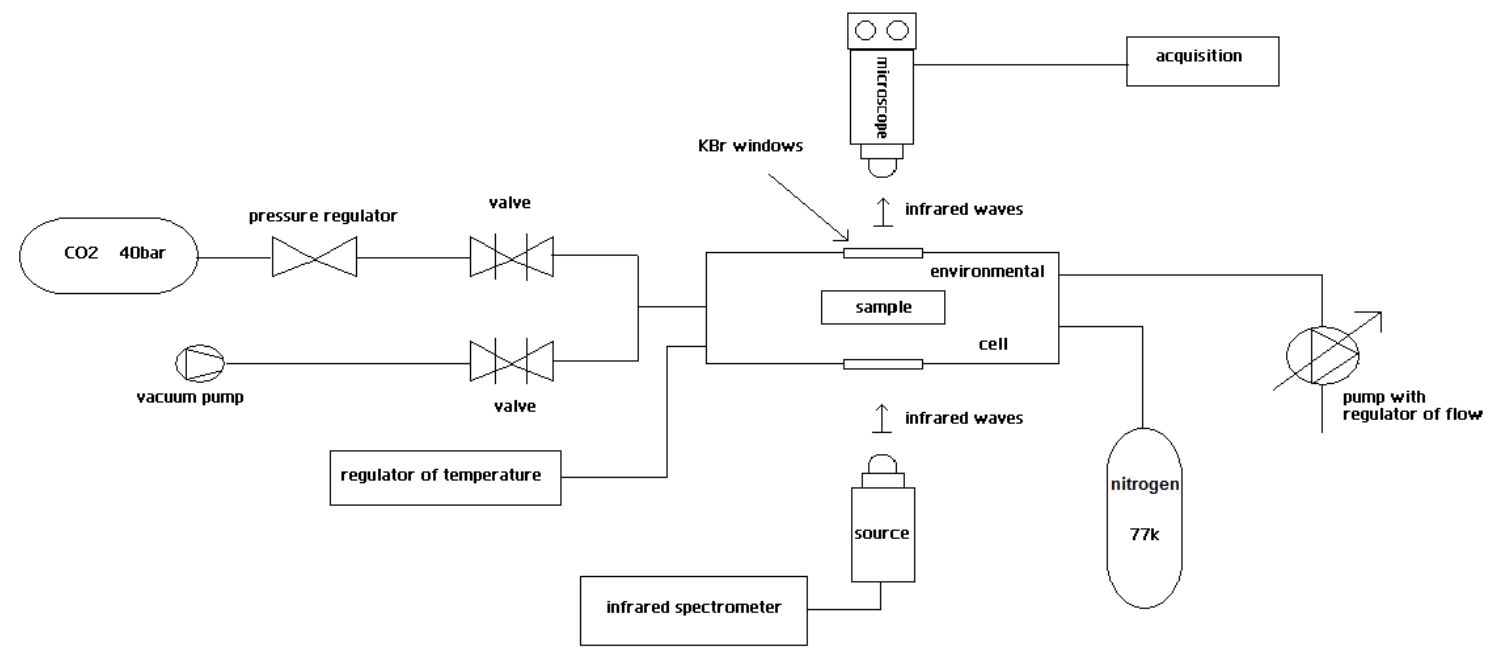

714 Figure 1. Schematic representation of the IR-CryoCell experimental setup, showing the main 715 parts such as temperature regulator, environmental cell, infrared microscope, valves, vacuum 716 pump, $\mathrm{CO}_{2}$ cylinder, liquid $\mathrm{N}_{2}$ reservoir. 


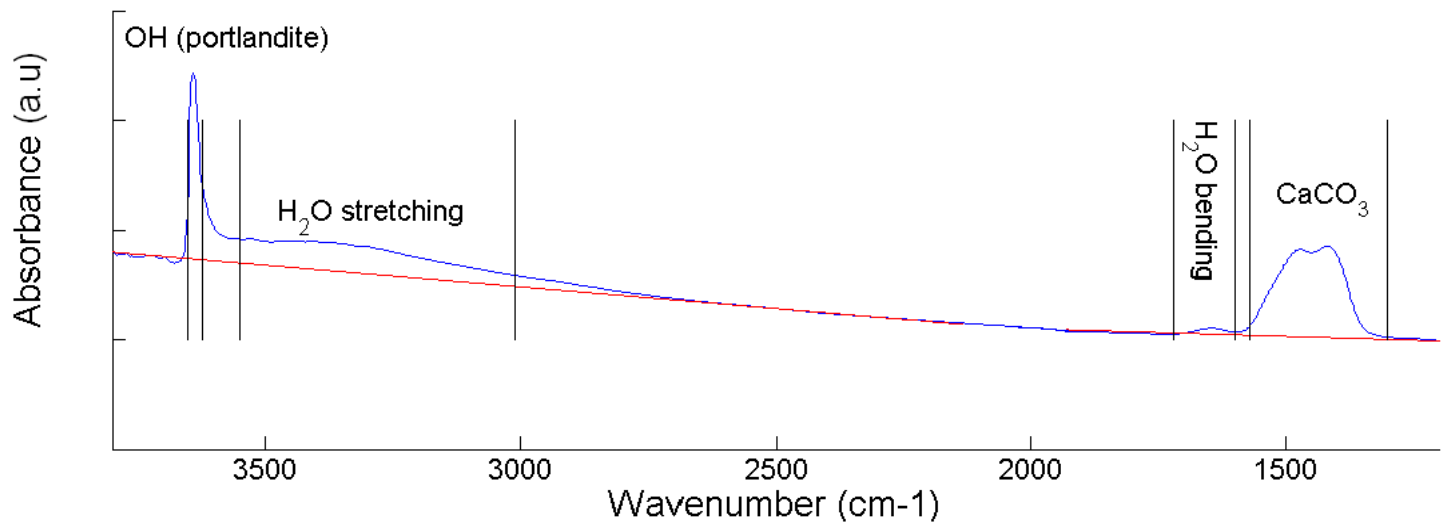

720

721

722 Figure 2 . Schematic representation for the calculation of the integrated band intensities of each 723 functional group (-OH, $\left.\mathrm{H}_{2} \mathrm{O}, \mathrm{MCO}_{3}\right)$, showing the continuum (in red) on an IR spectrum of 724 portlandite. 

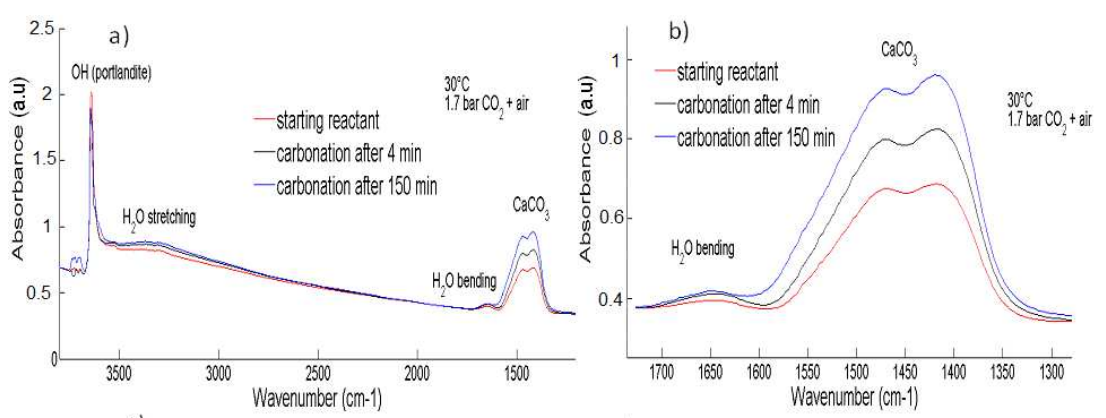

c)
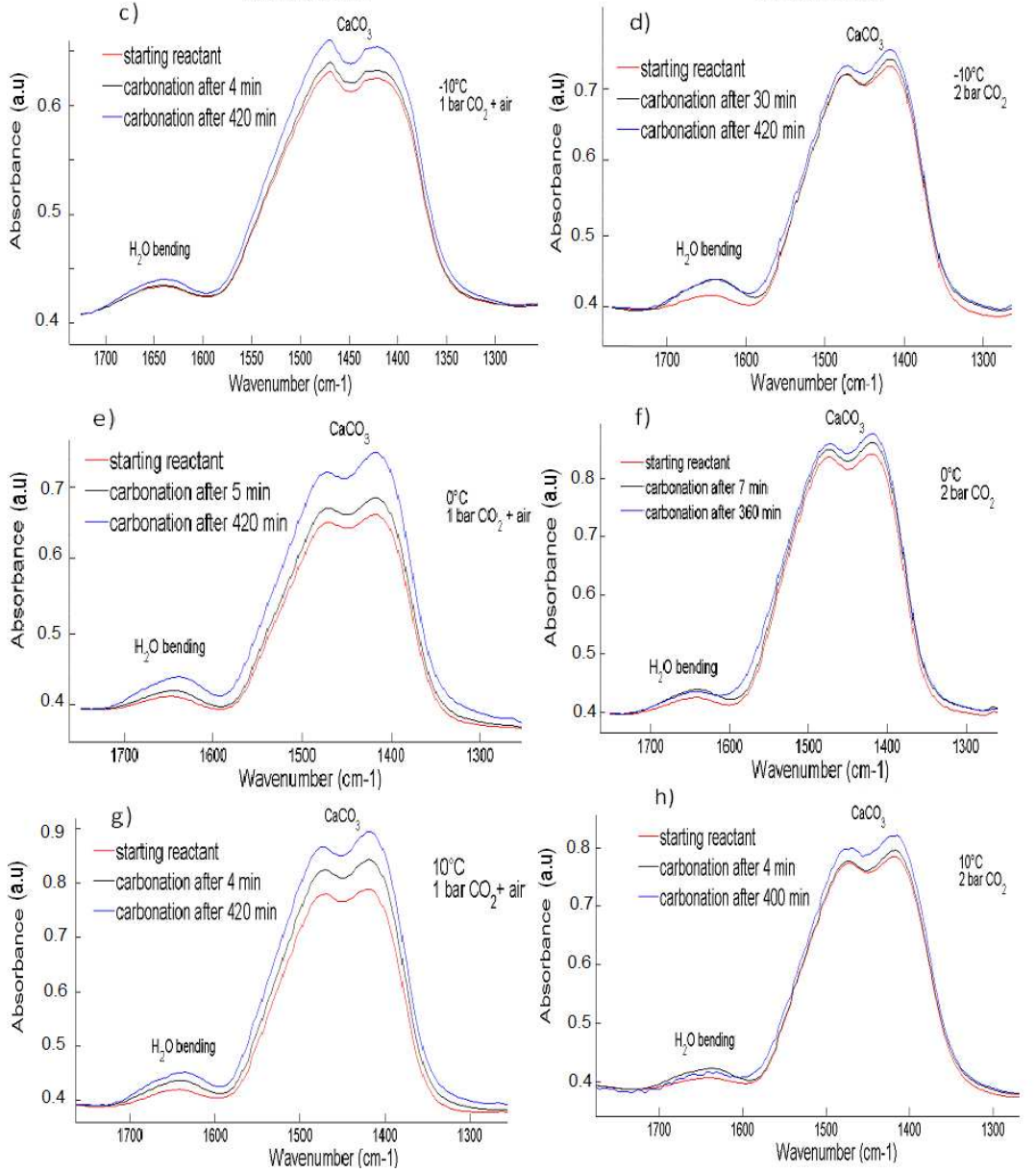

739 Figure 3. Evolution with time of the IR spectrum of calcium carbonate during carbonation at different temperatures and $\mathrm{CO}_{2}$ pressures. a) Full IR spectrum of portlandite at $30^{\circ} \mathrm{C}$ with 1.7 bar of $\mathrm{CO}_{2}$ in presence of air; (b) Carbonate band at $30^{\circ} \mathrm{C}$ under 1,7 bar of $\mathrm{CO}_{2}$ with air; (c) at $-10^{\circ} \mathrm{C}$ under 1 bar of $\mathrm{CO}_{2}$ with air; (d) at $-10^{\circ} \mathrm{C}$ under 2 bars of $\mathrm{CO}_{2}$; (e) at $0^{\circ} \mathrm{C}$ under 1 bar of $\mathrm{CO}_{2}$ with air ; (f) at $0^{\circ} \mathrm{C}$ under 2 bars of $\mathrm{CO}_{2} ;(\mathrm{g})$ at $10^{\circ} \mathrm{C}$ under 1 bar of $\mathrm{CO}_{2}$ with air; (h) at $10^{\circ} \mathrm{C}$ under 


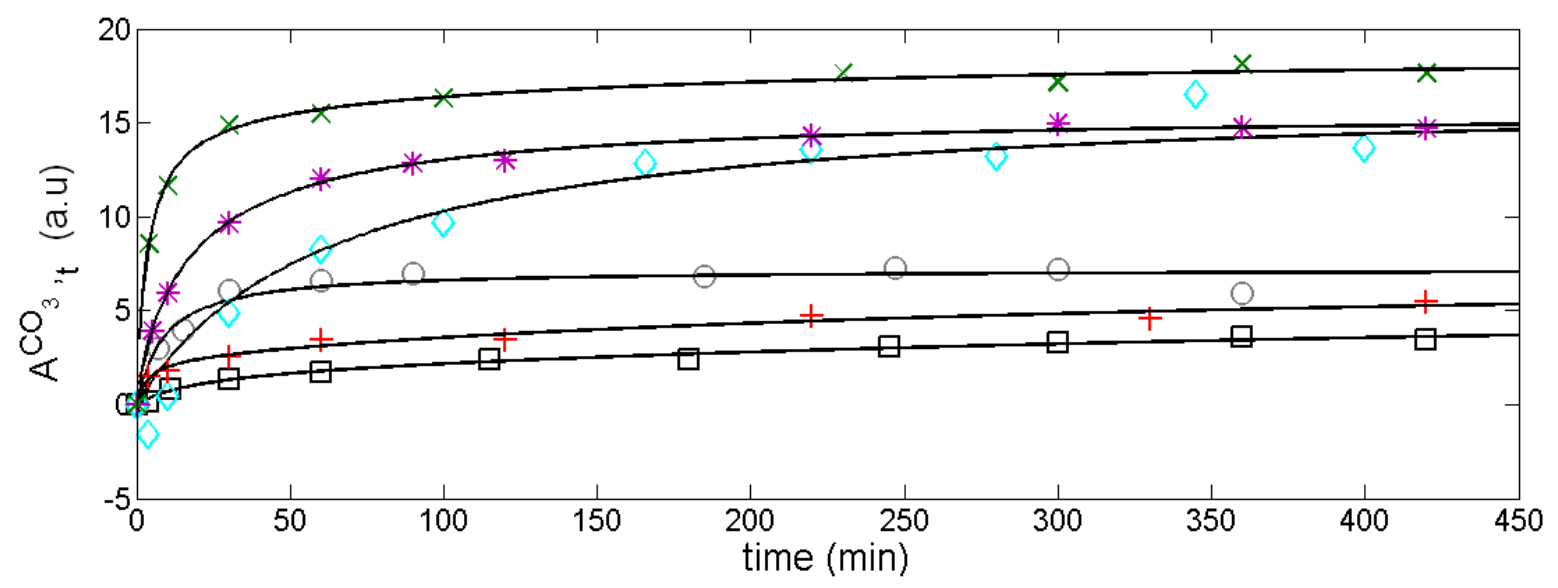

$\checkmark 10^{\circ} \mathrm{C}, 2$ bar $\mathrm{CO} 2$

Kinetic double-second-order-model

$00^{\circ} \mathrm{C}, 2 \mathrm{bar} \mathrm{CO} 2$

$-10^{\circ} \mathrm{C}, 2 \mathrm{bar} \mathrm{CO} 2$

$\times 10^{\circ} \mathrm{C}, 1 \mathrm{bar} \mathrm{CO} 2+$ air

$$
A^{\mathrm{CO} 3}{ }_{, t}=\frac{\left(A^{\mathrm{CO} 3}{ }_{{ }_{\text {max }}}\right) t}{t_{1 / 2}+t}+\frac{\left(A^{\mathrm{CO} 3}{ }_{{ }_{\text {max }}}\right) t}{t_{1 / 2}+t}
$$

* $0^{\circ} \mathrm{C}, 1$ bar $\mathrm{CO} 2+$ air

$+-10^{\circ} \mathrm{C}, 1$ bar $\mathrm{CO} 2+$ air

Kinetic double-second-order-model

748 Figure 4. Fits of the experimental kinetic data (carbonate band intensity) for gas-solid 749 carbonation of $\mathrm{Ca}$ hydroxide (portlandite) in various experimental conditions by using a kinetic 750 double-pseudo-second-order model and applying the non-linear least squares method. 

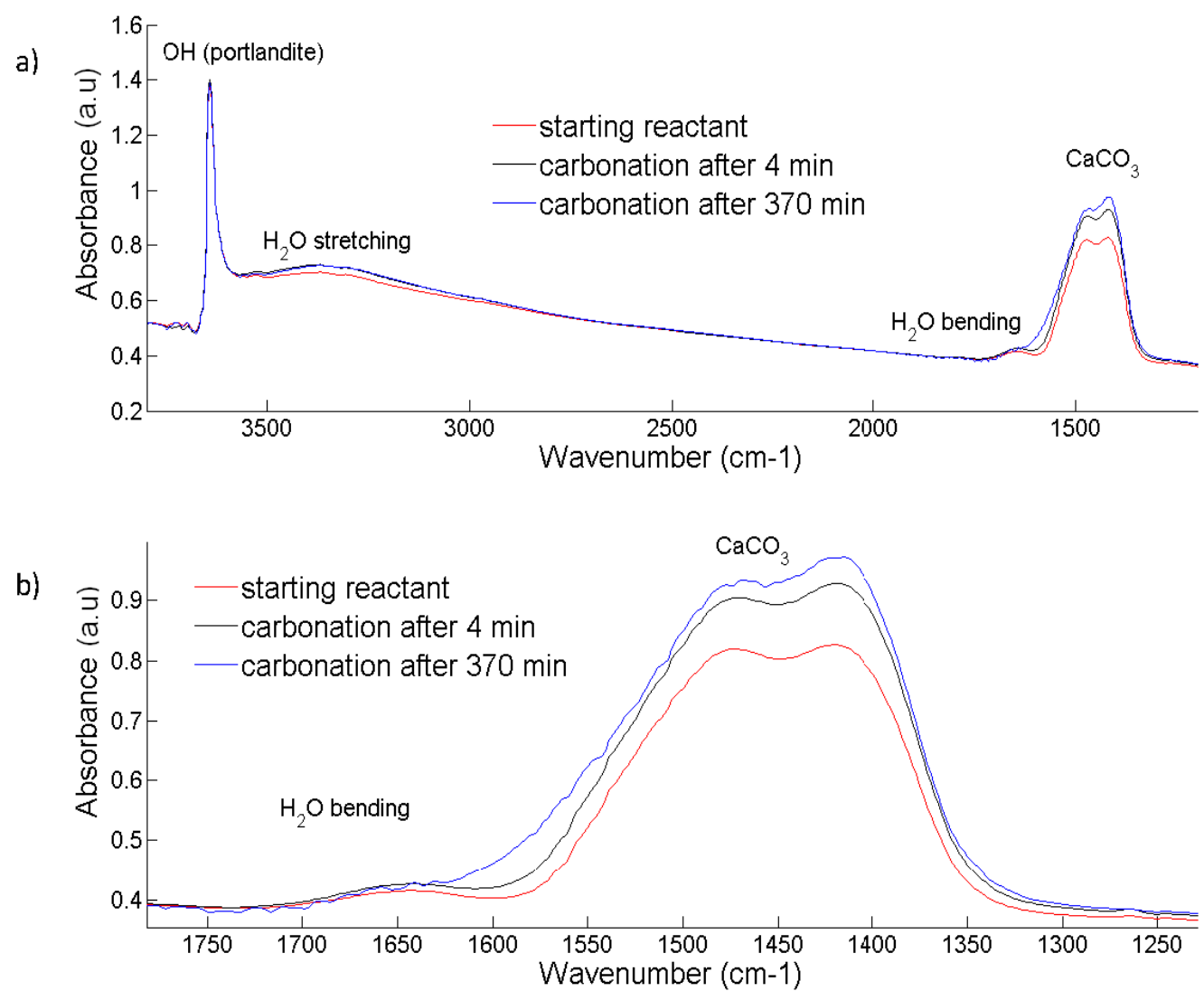

c)

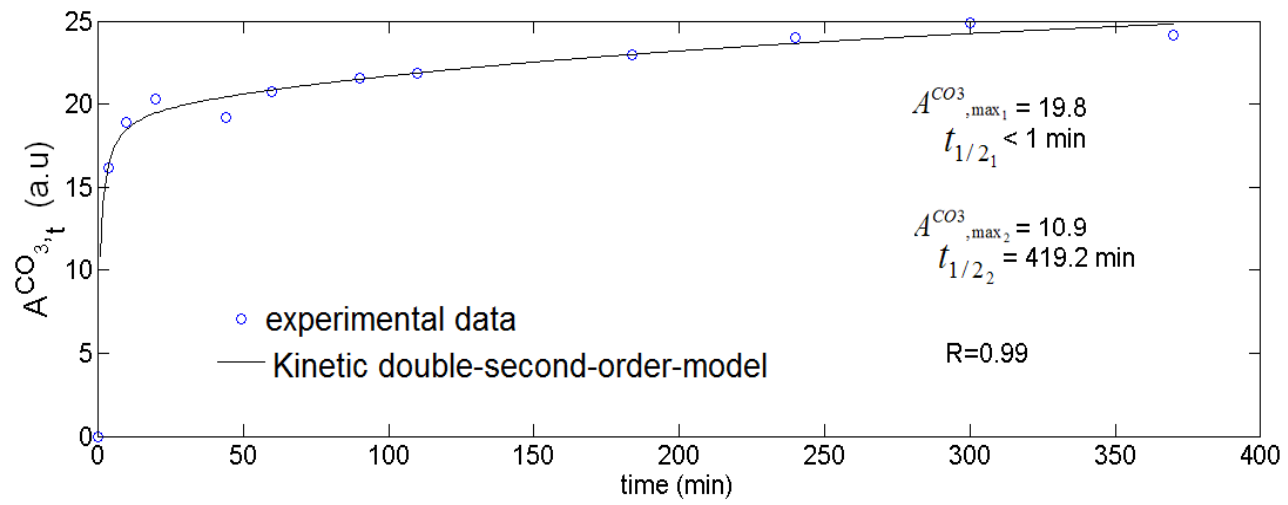

751 Figure 5. Evolution with time of the IR spectrum of $\mathrm{Ca}$ hydroxide (portlandite) during 752 carbonation at $25^{\circ} \mathrm{C}$ under $100 \mathrm{mbar} \mathrm{CO}_{2}$ : a) Full spectrum. b) Band of the carbonate group. c) 753 Fit of the experimental kinetic data (carbonate band intensity) for gas-solid carbonation by using 754 a kinetic double-pseudo-second-order model and applying the non-linear least squares method. 

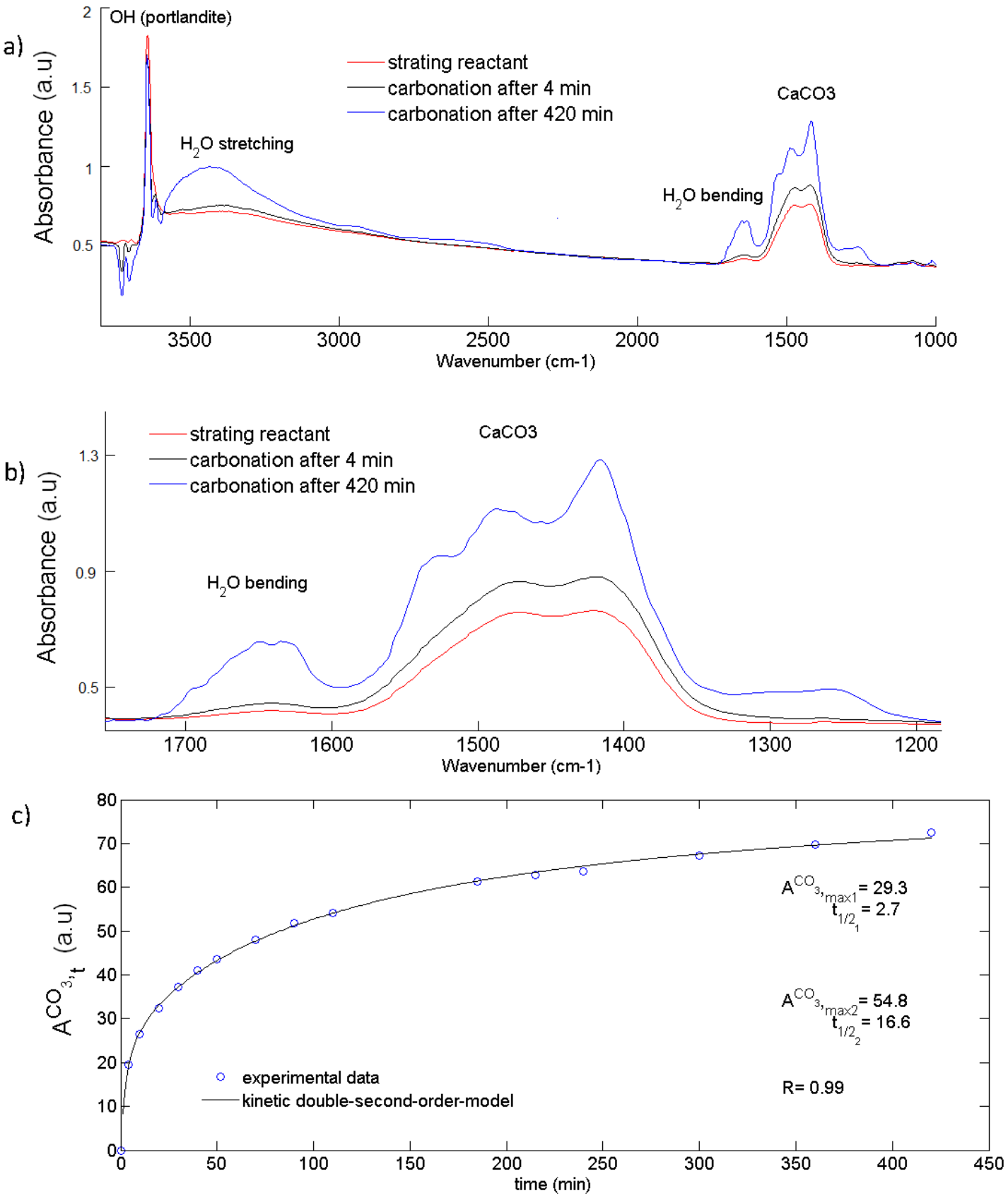

756 Figure 6. Evolution with time of the IR spectrum of $\mathrm{Ca}$ hydroxide (portlandite) during 757 carbonation at $25^{\circ} \mathrm{C}$ under 2 bar of $\mathrm{CO}_{2}$ : a) Full spectrum. b) Band of the carbonate group. c) Fit 758 of the experimental kinetic data (carbonate band intensity) for gas-solid carbonation by using a 759 kinetic double-pseudo-second-order model and applying the non-linear least squares method. 
a) ${ }^{1.6}[1.4$

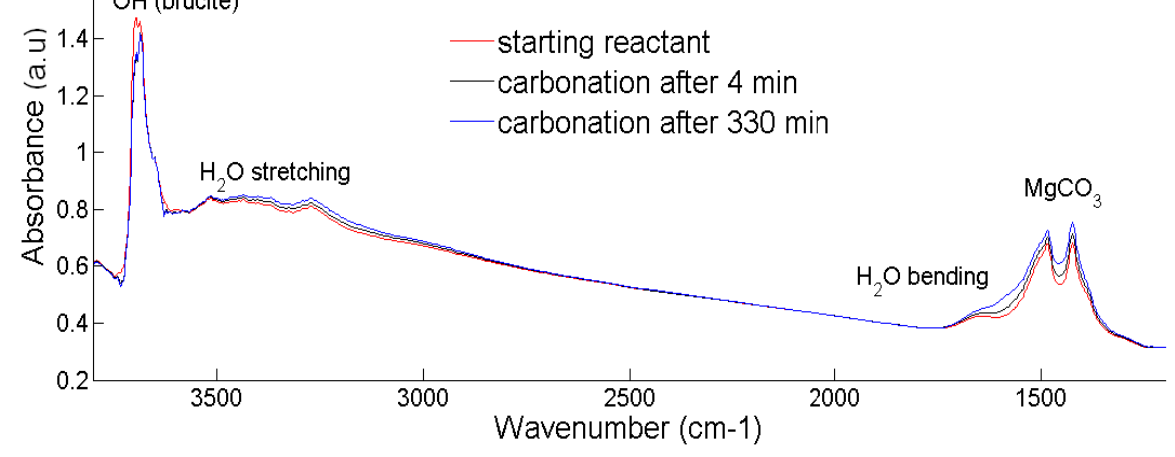

b) $\widehat{\supset} \mid$ starting reactant

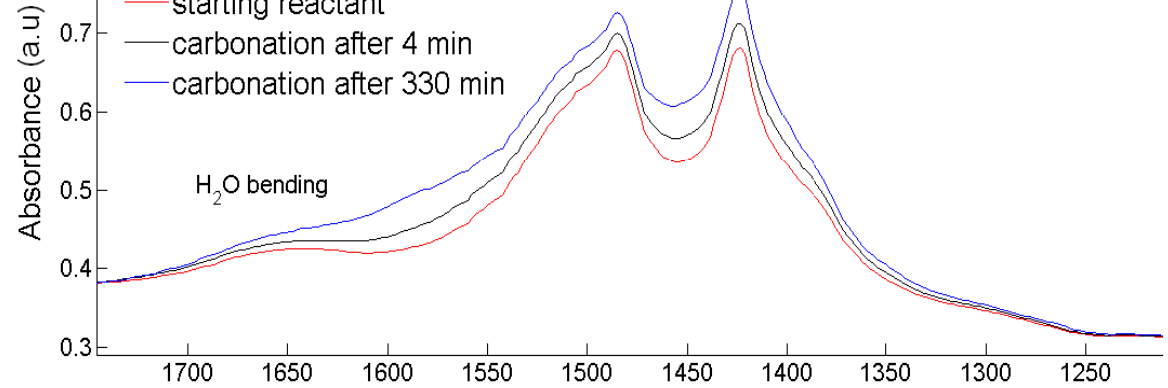

c)

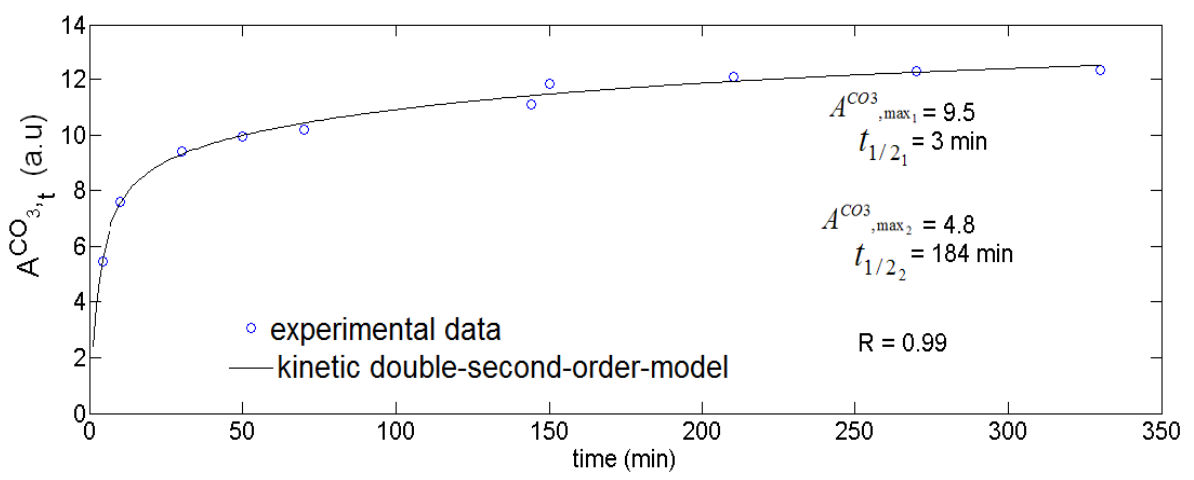

760

761 Figure 7. Evolution with time of the IR spectrum of the $\mathrm{Mg}$ hydroxide (brucite) during 762 carbonation at $25^{\circ} \mathrm{C}$ under 1 bar of $\mathrm{CO}_{2}$ with air: a) Full spectrum. b) Band of the carbonate group 763 c) Fit of the experimental kinetic data (carbonate band intensity) for gas-solid carbonation by 764 using a kinetic double-pseudo-second-order model and applying the non-linear least squares 765 method. 

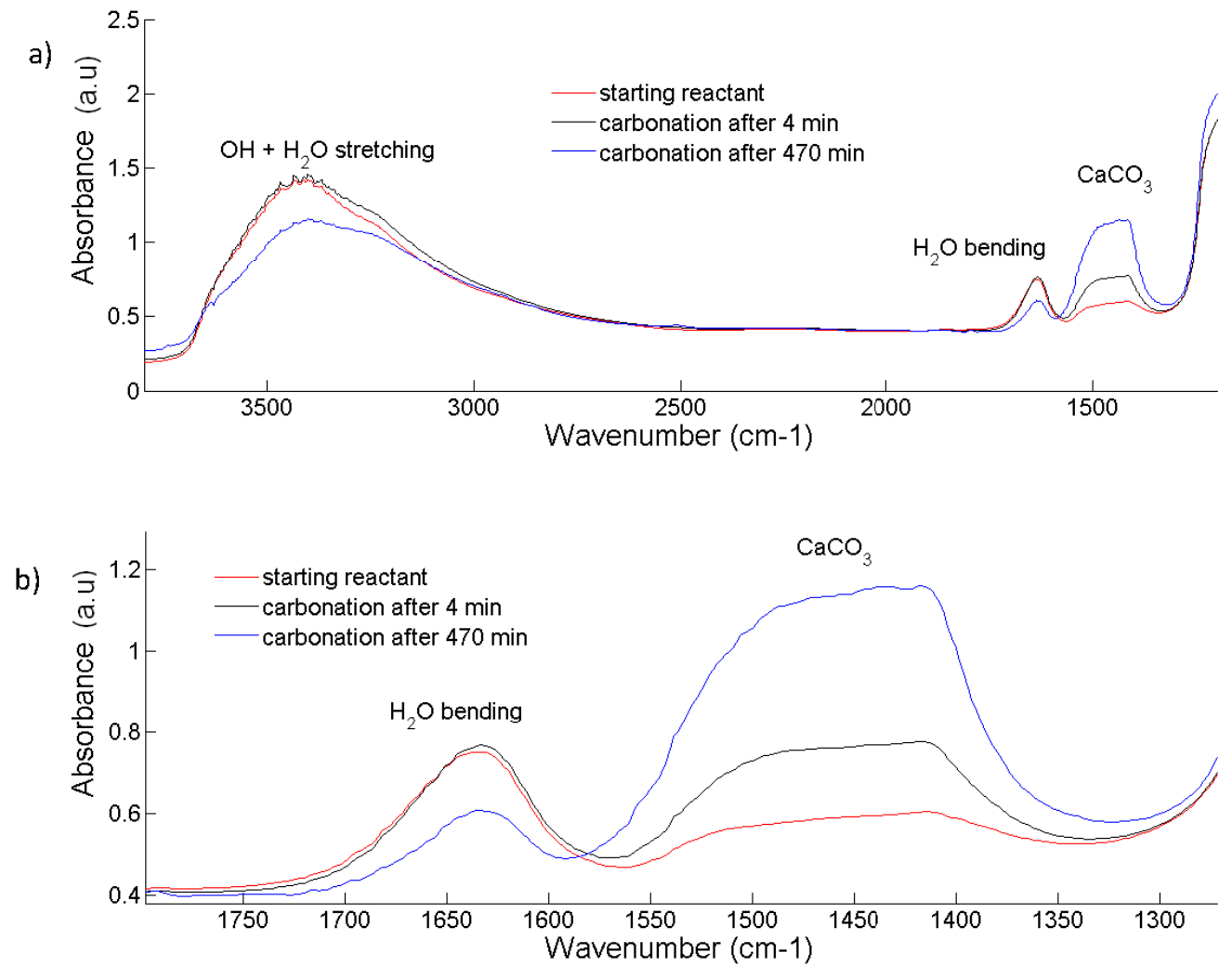

c)

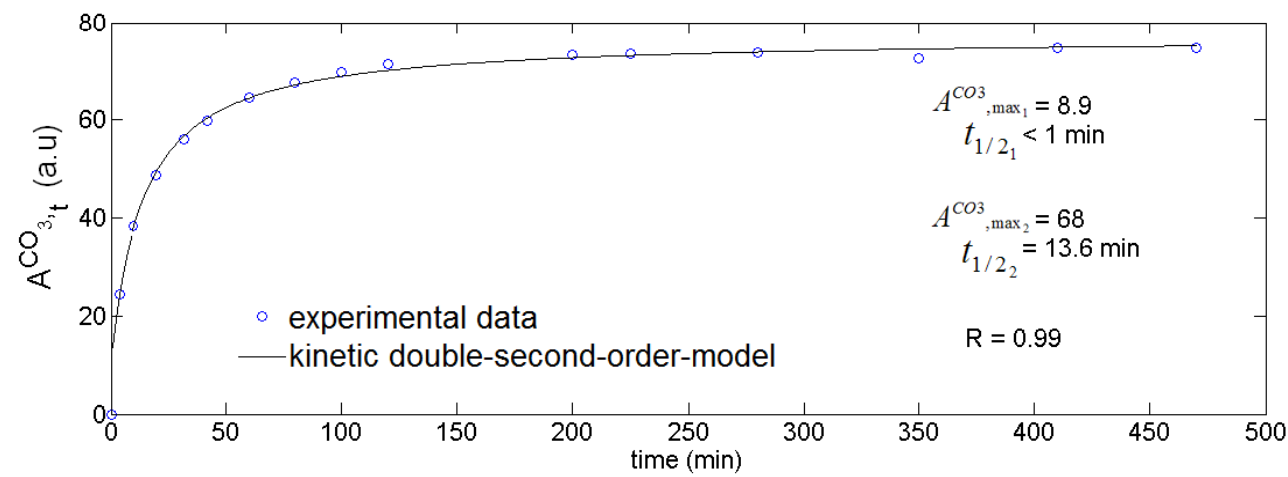

767 Figure 8. Evolution with time of the IR spectrum of amorphous $\mathrm{Ca}$ silicate hydrate during 768 carbonation at $25^{\circ} \mathrm{C}$ under 1 bar of $\mathrm{CO}_{2}$ with air: a) Full spectrum. b) Band of carbonate group. c) 769 Fit of the experimental kinetic data (carbonate band intensity) for gas-solid carbonation by using 770 a kinetic double-pseudo-second-order model and applying the non-linear least squares method. 


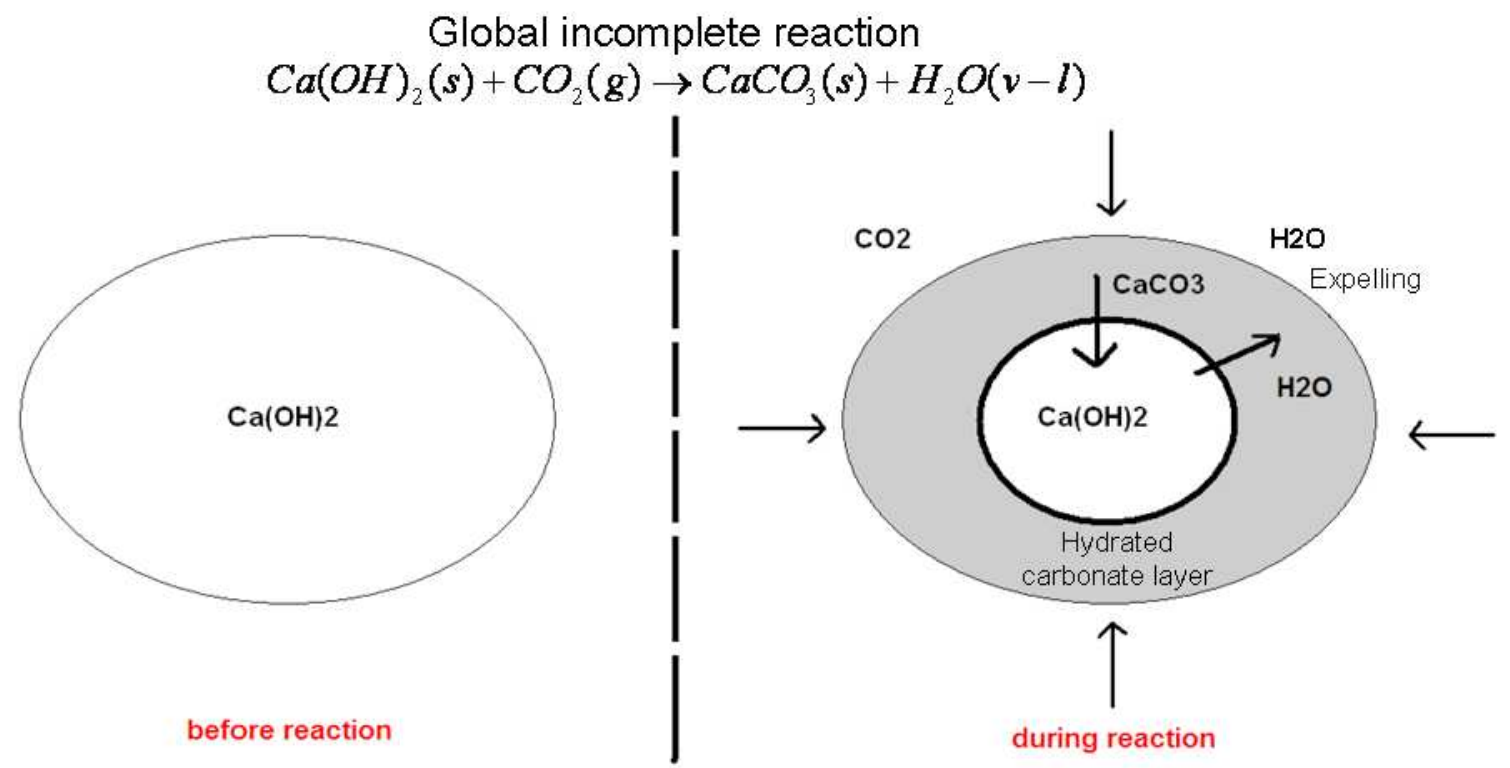

775

776 Figure 9. Schematic representation of the gas-solid carbonation of Ca hydroxide, showing the 777 growth of a hydrated calcium carbonate layer and the expelling of molecular water. 


\section{Binary oxides or amorphous silicates}

atmospheric conditions are enough to start the carbonation process

spontaneous hydration of precursor

$$
\mathrm{CaO}+\mathrm{H}_{2} \mathrm{O} \rightarrow \mathrm{Ca}(\mathrm{OH})_{2}
$$

unstable and react with atmospheric $\mathrm{CO}_{2}$

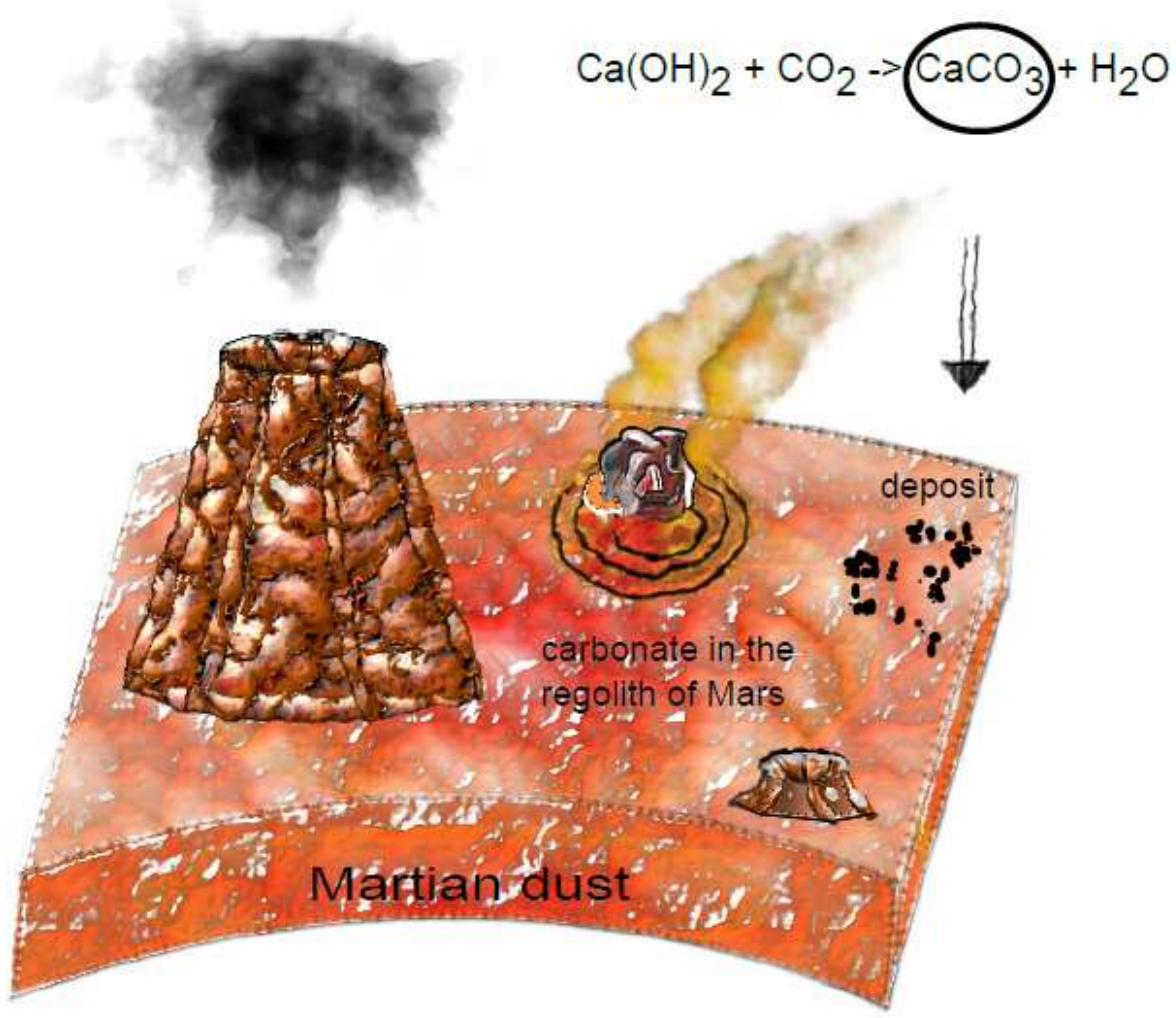

781 Figure 10. A schematic representation of a possible current formation mechanism at dust-CO2 interfaces of the calcium carbonate found at the Martian surface. 